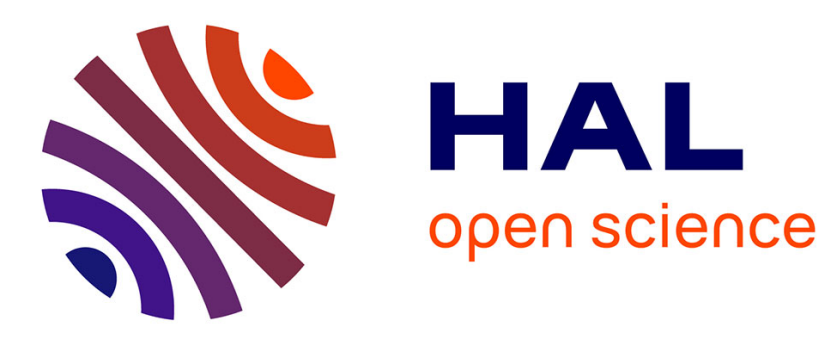

\title{
Glyphosate-degrading behavior of five bacterial strains isolated from stream biofilms
}

Florent Rossi, Louis Carles, Florence Donnadieu, Isabelle Batisson, Joan

Artigas

\section{- To cite this version:}

Florent Rossi, Louis Carles, Florence Donnadieu, Isabelle Batisson, Joan Artigas. Glyphosatedegrading behavior of five bacterial strains isolated from stream biofilms. Journal of Hazardous Materials, 2021, 420, pp.126651. 10.1016/j.jhazmat.2021.126651 . hal-03406037

\section{HAL Id: hal-03406037 \\ https://hal.science/hal-03406037}

Submitted on 27 Oct 2021

HAL is a multi-disciplinary open access archive for the deposit and dissemination of scientific research documents, whether they are published or not. The documents may come from teaching and research institutions in France or abroad, or from public or private research centers.
L'archive ouverte pluridisciplinaire HAL, est destinée au dépôt et à la diffusion de documents scientifiques de niveau recherche, publiés ou non, émanant des établissements d'enseignement et de recherche français ou étrangers, des laboratoires publics ou privés. 
2

3

4

5

6

7

8

9

10

11

12

13

14

15

16

17 18

\section{Glyphosate-degrading behaviour of five bacterial strains isolated from stream biofilms}

Florent Rossi ${ }^{1}$, Louis Carles ${ }^{2}$, Florence Donnadieu ${ }^{1}$, Isabelle Batisson ${ }^{1}$ and Joan Artigas ${ }^{1, *}$ (1)

1) Université Clermont-Auvergne, CNRS, Laboratoire Microorganismes : Génome et Environnement, F-63000 Clermont-Ferrand, France.

2) Department of Environmental Toxicology (Utox), Swiss Federal Institute of Aquatic Science and Technology (Eawag), Dübendorf, Switzerland. (1) (1) 11 (3) (4)

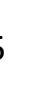

*Corresponding author:

8 Joan Artigas

Laboratoire Microorganismes : Génome et Environnement

1 Impasse Amélie Murat,

TSA 60026, CS 60026

63178 Aubière Cedex, France

Tel : +33473407473

Fax : +33473407670

E-mail: joan.artigas_alejo@uca.fr

Running head: Glyphosate as phosphorus source

Keywords: herbicide, AMPA, sarcosine, degradation, C-P lyase, periphyton. 


\section{SUMMARY}

The present study investigates the individual degrading behaviour of bacterial strains isolated from glyphosate-degrading stream biofilms. In this aim, biofilms were subjected to enrichment experiments using glyphosate or its metabolite AMPA (aminomethyl phosphonic acid) as the sole phosphorus source. Five bacterial strains were isolated and taxonomically affiliated to Ensifer sp. CNII15, Acidovorax sp. CNI26, Agrobacterium tumefaciens CNI28, Novosphingobium sp. CNI35 and Ochrobactrum pituitosum CNI52. All strains were capable of completely dissipating glyphosate after 125 to $400 \mathrm{~h}$ and AMPA after 30 to $120 \mathrm{~h}$, except for Ensifer sp. CNII15 that was not able to dissipate glyphosate but entirely dissipated AMPA after 200 h. AMPA dissipation was overall faster than glyphosate dissipation. The five strains degraded AMPA completely since formaldehyde and/or glycine accumulation was observed. During glyphosate degradation, the strain CNI26 used the C-P lyase degradation pathway since sarcosine was quantitatively produced, and C-P lyase gene expression was enhanced $30 \times$ compared to the control treatment. However, strains CNI28, CNI35 and CNI52 accumulated both formaldehyde and glycine after glyphosate transformation suggesting that both C-P lyase and/or glyphosate oxidase degradation pathways took place. Our study shows different and complementary glyphosate degradation pathways for bacteria co-existing in stream biofilms.

\section{INTRODUCTION}

Streams and rivers account for the most impacted ecosystems on the planet since they have been heavily exploited by humans and often used as final receptors of pollution (Meybec 2003). Urbanization, industry, land-use changes and watercourse alterations are the main proximate causes at the origin of river ecosystems changes which results in physical habitats and water chemistry alterations, and shifts in aquatic biodiversity, among other consequences (Malmqvist and Rundle 2002). Alterations in water chemistry have existed for millennia in streams and rivers (Meybeck and Helmer 1989) and the increasing global chemical pollution of surface waters with largely unknown short and long-term effects on aquatic life and on human health is one of the key problems facing humanity (Schwarzenbach et al. 2010). Therefore, the necessity of limiting threats of problematic chemicals at their source instead of costly remediation processes have been widely proposed in the scientific literature 
(Vörösmarty et al. 2010, Schwarzenbach et al. 2010) and suggested in national and international policies (Ecophyto II+ 2018, Lamichhane et al. 2016, Directive 2009/128/EC). Because biofilms constitute a highly reactive surface area for the sorption and metabolism of contaminants in running waters (Araya et al. 2003, Lawrence et al. 2001, Tien et al. 2013), their study to alleviate specific water pollution problems becomes a potential solution. However, few studies have investigated the natural potential of aquatic biofilms for the removal of chemicals (e.g. Wang et al. 2016b, Carles et al. 2019).

Glyphosate ( $\mathrm{N}$-[phosphonomethyl] glycine) has become the most commonly used herbicide worldwide (Benbrook 2016, Duke and Powles 2008) with about 600 to 750 thousand tonnes used annually in the world and an expected 740 to 920 thousand tonnes to be used by 2025 (Maggi et al. 2020). The potential of glyphosate retention in topsoil layers is high due to its strong sorption on clay, iron and aluminium oxide particles (Borggaard and Gimsing 2008, Okada et al. 2016, Rampazzo et al. 2013, Sidoli et al. 2016, Vereecken 2005). Consequently, the immediate leaching of aqueous glyphosate residue is relatively low. However, $98 \%$ of residues adsorbed onto these soil minerals are prone to remobilize if specific agricultural practices are applied (i.e. tillage and ploughing in combination with irrigation and soil pH variations, Maggi et al. 2020). Yang et al. (2015) showed that up to 14 $\%$ of applied glyphosate is transported by runoff and suspended load from clay loam soil with a rain intensity of $1 \mathrm{~mm} / \mathrm{min}$ for $1 \mathrm{~h}$. Therefore, glyphosate and AMPA can reach streams and rivers through chronic and/or peak exposure events, the latter occurring over hours to a few days depending on the intensity and duration of rain events (Daouk et al. 2013). Glyphosate and AMPA concentrations during peaks can reach up to hundreds of micrograms per litre, although basal concentrations rarely exceed a few micrograms per litre (Battaglin et al. 2014, Carles et al. 2019). Also, it must be noted that other sources of AMPA such as detergents, fire retardants, anti-corrosives and anti-scaling agents can enter streams and rivers through wastewater treatment plant effluents (Grandcoin et al. 2017, Nowack 2003, Struger et al. 2015, Studnik et al. 2015). Generalized exposure to glyphosate makes aquatic microbial communities in sediments prone to acquire tolerance (Bonnineau, unpublished data) and develop transformation and/or mineralization capacities in periphyton (Carles et al. 2019, Artigas et al. 2020).

Glyphosate degradation is essentially driven by microorganisms (Mallat and Barceló, 1998). Up to now, two main biodegradation pathways have been described (Figure 1): i) the glyphosate oxidase pathway (or AMPA pathway), which involves the cleavage of the C-N bond of the glyphosate molecule by glyphosate oxidoreductase or glycine oxidase enzymes 
(+FAD), releasing both AMPA and glyoxylate. Glyoxylate is further metabolized into glycine or via the glyoxylate cycle into microbial biomass and carbon dioxide (Borggaard and Gimsing 2008), while AMPA can be degraded by C-P lyase enzymes, releasing inorganic phosphorus and methylamine, the latter being degraded into formaldehyde and incorporated into microbial biomass. And ii) the C-P lyase pathway (or sarcosine pathway), which involves the cleavage of the C-P bond of the glyphosate molecule by C-P lyase enzymes (encoded by the phn operon, Hove-Jensen et al. 2014), releasing both inorganic phosphate and sarcosine. Sarcosine may further degrade into glycine and formaldehyde by sarcosine oxidase to finally incorporate the microbial biomass. The prevalent glyphosate degradation pathway employed by bacteria is the sarcosine pathway (13 strains) followed by the AMPA pathway ( 8 strains) and some strains are able to use both AMPA and sarcosine pathways (4 strains) (Zhan et al. 2018). In addition, molecular dynamics simulation studies confirmed the stability of the enzyme-substrate complex for glyphosate oxidoreductase and C-P lyase demonstrating that both enzymes could be preferred in glyphosate biodegradation (Bhatt et al. 2021).

Figure 1. Glyphosate and AMPA degradation pathways in the environment.

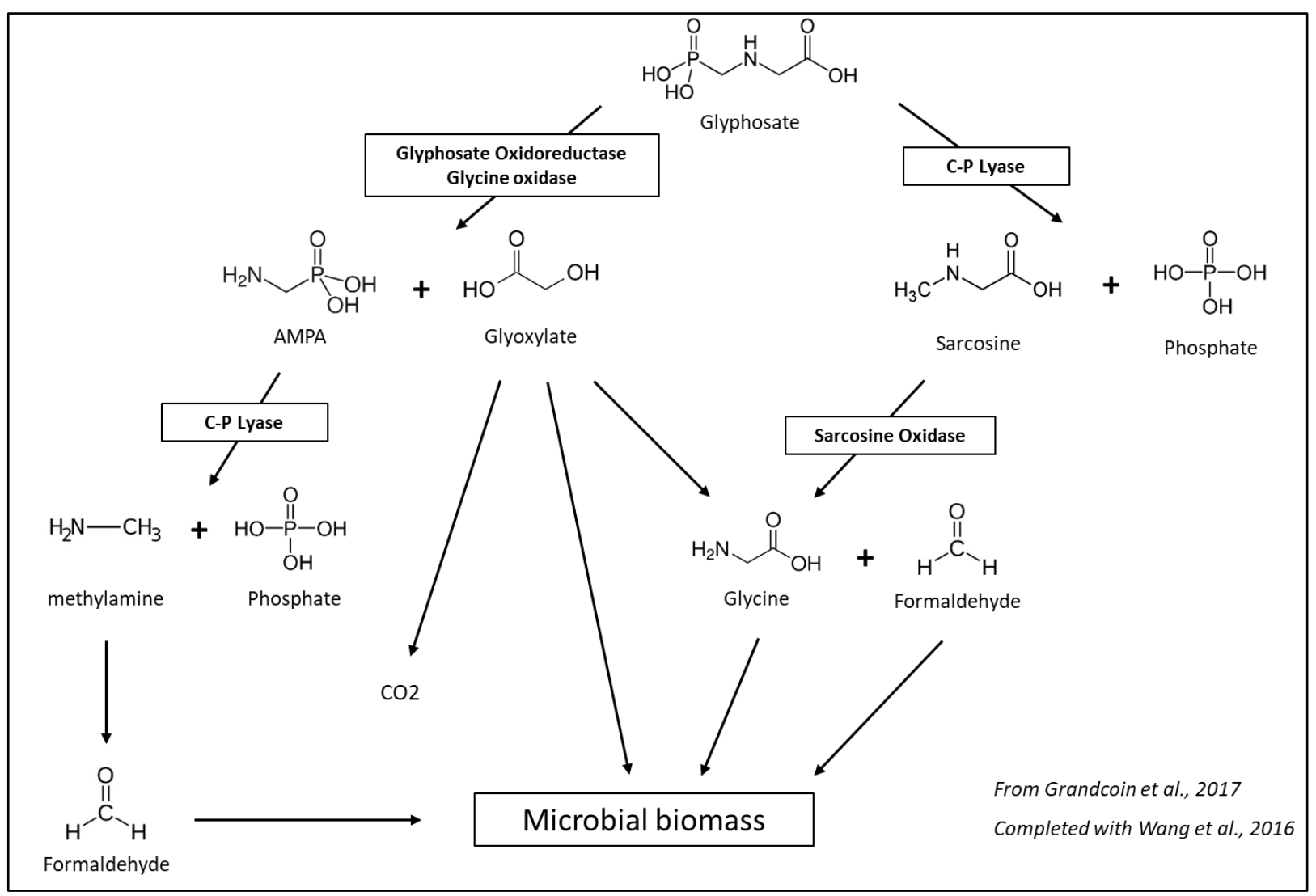


The occurrence of either of these pathways in aquatic systems is still unknown, though projections indicate that the oxidative pathway prevails in soils worldwide (Maggi et al. 2020). Up to now, most of the bacterial strains studied are capable to convert glyphosate to AMPA (Pseudomonas sp. SG-1 (Talbot et al. 1984), Agrobacterium radiobacter SW9 (Mcauliffe et al. 1990) and Ochrobactrum anthropi GPK 3 (Sviridov et al. 2012)), even in bacteria that have never been exposed to glyphosate previously, possibly highlighting widespread detoxification mechanisms (Sviridov et al. 2015). Furthermore, the C-P bond has been reported to be cleaved by several other strains (Achromobacter sp. MPS 12A (Sviridov et al. 2012) and Arthrobacter sp. GLP-1 (Pipke et al. 1987)). This highlights the ability of microbes to use both glyphosate and AMPA as a carbon $(\mathrm{C})$ and phosphorus $(\mathrm{P})$ source for their metabolism, although this has been shown to be closely linked with dissolved nutrient availability in water (Carles et al. 2019, Hove-Jensen et al. 2014, Sviridov et al. 2014, Zhang and van der Donk 2012, Bazot and Lebeau 2008). However, it must be noted that most of the knowledge so far comes from bacteria isolated from soils and activated sludge while few studies have investigated glyphosate degradation pathways by bacteria in streams and rivers (Zhan et al. 2018, Jacob et al. 1988).

In order to improve our knowledge on glyphosate and AMPA biodegradation potential in streams, we used glyphosate-degrading biofilms (Carles et al. 2019) in enrichment cultures using glyphosate as the sole $\mathrm{P}$ source. Five bacterial strains were isolated and their ability to use glyphosate and AMPA as P source investigated. Each strain was tested separately for glyphosate and AMPA degradation and compared to a control supplemented with $\mathrm{K}_{2} \mathrm{HPO}_{4}$. Glyphosate and its metabolites (AMPA, sarcosine, formaldehyde and glycine) were analysed during experiments in order to identify the degradation pathway(s) used by each strain. Because our study is the first literature report of an Acidovorax sp. strain capable to degrade glyphosate, we focused on the molecular mechanisms of the strain Acidovorax CNI26 responsible for glyphosate/AMPA degradation. We first hypothesize faster degradation of AMPA than glyphosate since AMPA is easier to degrade and less toxic for aquatic microorganisms compared to glyphosate. Accordingly, the biomass growth of strains will also be faster with AMPA than glyphosate. Second, the Acidovorax CNI26 strain is expected to rapidly overexpress the C-P lyase gene in the presence of AMPA, while overexpression on both C-P lyase and glyphosate oxidase genes can be displayed in the presence of glyphosate. The expression of these two genes will depend on glyphosate and AMPA concentration variation in the media throughout the experiment. The objectives of this study were i) to analyse the glyphosate and AMPA-degrading behaviour of five bacterial strains isolated from 
150

151

152

153

154

155

156

157

158

159

160

161

162

163

164

165

166

167

168

169

170

171

172

173

174

175

176

177

178

179

180

181

stream biofilms and ii) to investigate the pathway employed by the strain Acidovorax CNI26 to degrade glyphosate and AMPA by targeting the C-P lyase and glyphosate oxidase genes.

\section{MATERIALS AND METHODS}

\subsection{Chemicals and media}

Glyphosate (N-[phosphonomethyl] glycine (purity $\geq 98 \%$ )), AMPA (aminomethyl phosphonic acid (purity $\geq 99 \%$ )) and $\mathrm{K}_{2} \mathrm{HPO}_{4}$ (purity $\geq 98 \%$ ) were purchased from Sigma Aldrich (France). Acid phenol, TRIzol ${ }^{\circledR}$ and TURBO DNAse were purchased from ThermoFisher Scientific (France). MOPS ${ }^{\mathrm{CN}}$ medium (P-free), $\mathrm{pH} 7.4$, was made up of: 40 mM MOPS (3-(N-Morpholino)propanesulfonic acid), $4 \mathrm{mM}$ tricine, $10 \mu \mathrm{M} \mathrm{FeSO}_{4}, 276 \mu \mathrm{M}$ $\mathrm{K}_{2} \mathrm{SO}_{4}, 0.5 \mu \mathrm{M} \mathrm{CaCl}_{2}, 525 \mu \mathrm{M} \mathrm{MgCl} 2,50 \mathrm{mM} \mathrm{NaCl}, 30 \mathrm{mM}\left(\mathrm{NH}_{4}\right)_{6} \mathrm{Mo}_{7} \mathrm{O}_{24} .4 \mathrm{H}_{2} \mathrm{O}, 4 \mu \mathrm{M}$ $\mathrm{H}_{3} \mathrm{BO}_{3}, \quad 0.3 \mu \mathrm{M} \mathrm{CoCl}_{2} \cdot 6 \mathrm{H}_{2} \mathrm{O}, 0.1 \mu \mathrm{M} \mathrm{CuSO}_{4} .5 \mathrm{H}_{2} \mathrm{O}, 0.8 \mu \mathrm{M} \mathrm{MnCl}_{2} .4 \mathrm{H}_{2} \mathrm{O}, 0.1 \mu \mathrm{M}$ $\mathrm{ZnSO}_{4} .7 \mathrm{H}_{2} \mathrm{O}, 0.3 \mu \mathrm{M}$ Thiamine $\mathrm{HCl}, 22 \mathrm{mM}$ Glucose, $9.5 \mathrm{mM} \mathrm{NH}_{4} \mathrm{Cl}$. MOPS ${ }^{\mathrm{CN}}$ agar plates were prepared by adding $1.5 \%(\mathrm{w} / \mathrm{v})$ agar into the liquid media.

\subsection{Enrichment cultures and isolation of bacteria}

Glyphosate- and AMPA-enrichment cultures as described by Batisson et al. (2009) were run with stream biofilms from Carles et al. (2019). From this experiment, we selected river biofilms (namely, Ups_LowP_LowG and Dws_LowP_HighG), having proven their strong capacity to dissipate glyphosate without AMPA accumulation in the media, for subsequent isolation of glyphosate/AMPA-degrading strains. Biofilms were scraped, pooled, and suspended in $2 \mathrm{~mL}$ of sterile $0.8 \% \mathrm{NaCl}$ solution. Biofilm suspensions were then centrifuged $\left(13,000 \mathrm{~g}, 10 \mathrm{~min}\right.$ at $\left.4{ }^{\circ} \mathrm{C}\right)$, and the pellet was washed three times with $2 \mathrm{~mL}$ of sterile $0.8 \%$ $\mathrm{NaCl}$ solution in order to remove glyphosate or AMPA residues. Biofilm pellets were suspended in $2 \mathrm{~mL}$ of sterile $0.8 \% \mathrm{NaCl}$ solution and homogenised. This biofilm suspension was used as the inoculum for enrichment cultures.

A volume of $125 \mu \mathrm{L}$ of each biofilm suspension was added to $12.5 \mathrm{~mL}$ of $\mathrm{MOPS}^{\mathrm{CN}}$ media supplemented with glyphosate $(0.5 \mathrm{mM})$ in $50 \mathrm{~mL}$ flasks. Phosphorus contained in the glyphosate molecule was the only source of $\mathrm{P}$ in the culture media. Two additional enrichment steps were carried out every 3 weeks by sub-culturing $125 \mu \mathrm{L}$ of the culture into 
$12.5 \mathrm{~mL}$ of fresh medium containing 2 and $4 \mathrm{mM}$ of glyphosate, respectively. During the enrichment culture steps, the flasks were incubated at room temperature in an orbital shaker at $100 \mathrm{rpm}$ in the dark. The cultures were sampled at the beginning (day 0) and the end (day 21) of each enrichment step to determine glyphosate concentration (see details in section 2.4). At the end of the third enrichment step, cultures were spread for bacterial isolation on MOPS ${ }^{\mathrm{CN}}$ agar plates containing the same glyphosate concentrations as in liquid MOPS ${ }^{\mathrm{CN}}(4 \mathrm{mM})$. Pure colonies were tested separately for their capacity to transform glyphosate and AMPA in liquid MOPS $^{\mathrm{CN}}$ media containing $0.5 \mathrm{mM}$ of glyphosate. Liquid cultures were incubated and sampled for glyphosate and AMPA concentration determination at the same incubation conditions described above. Among the isolates, 5 pure strains degrading glyphosate and/or AMPA in MOPS ${ }^{\mathrm{CN}}$ medium were selected for further chemical and molecular characterization.

\subsection{Identification and phylogenetic analysis of bacteria}

The identification of the 5 strains degrading glyphosate and/or AMPA was carried out by $16 \mathrm{~S}$ rDNA gene sequencing as described by Batisson et al. (2009). The sequences were deposited in GenBank under the accession numbers MN017826, MN017827, MN017828, MN017829 and MN017830, corresponding to isolates CNII15, CNI26, CNI28, CNI35 and CNI52, respectively.

Phylogenetic analysis based on 16S rDNA gene sequences was carried out by multiple alignments (Clustal $\Omega$ ) followed by the construction of a phylogenetic tree (MEGA 6.0 software). In addition to the $16 \mathrm{~S}$ rDNA sequences of the 5 newly isolated strains (present study), sequences from previously isolated glyphosate-degrading strains were also included in the analysis. Only one sequence per genus was included in the analysis, either the 16S rDNA gene sequence of the glyphosate-degrading strain described, or the sequence of a corresponding genus/species if the 16S rDNA degrading strain sequence was not available.

\subsection{Biodegradation tests with bacteria}

The use of glyphosate, AMPA and $\mathrm{K}_{2} \mathrm{HPO}_{4}$ as $\mathrm{P}$ sources by the five strains was determined separately. These strains were inoculated at $10^{5}$ cell $\mathrm{mL}^{-1}$ in $120 \mathrm{~mL}$ of MOPS ${ }^{\mathrm{CN}}$ liquid media supplemented with $0.132 \mathrm{mM}$ of P-equivalents of glyphosate, AMPA or $\mathrm{K}_{2} \mathrm{HPO}_{4}$ in $225 \mathrm{~mL}$ 
polyethylene flasks. Non-inoculated media served as abiotic controls. Each experiment was carried out in triplicate. The cultures were incubated in the dark at room temperature and 100 rpm agitation for 2 weeks. Six samplings were performed $(6 \times 1 \mathrm{~mL})$ to monitor strain growth (Optical Density $\mathrm{OD}_{\lambda}=600 \mathrm{~nm}$ ) and variation in concentrations of glyphosate, AMPA, $\mathrm{K}_{2} \mathrm{HPO}_{4}$, sarcosine, formaldehyde and glycine over time. The same experiment was repeated later on, in the exact same conditions and $5 \mathrm{~mL}$ of culture was recovered to assess gene expression kinetics of C-P lyase and glyphosate oxidase in the CNI26 strain. All samples were kept frozen at $-20{ }^{\circ} \mathrm{C}$ before glyphosate and glyphosate-metabolite concentration analysis.

Bacterial Abundance: Bacterial abundance during biodegradation tests was estimated in triplicate using a conversion factor obtained from the correspondence curves between optical density at $600 \mathrm{~nm}$ and cell counting on flow cytometry. For each of the five bacterial strains, correspondence curves were obtained by following the growth of one colony in $10 \mathrm{~mL}$ of MOPS ${ }^{\mathrm{CN}}$ liquid media supplemented with $0.132 \mathrm{mM}$ of $\mathrm{K}_{2} \mathrm{HPO}_{4}$ every 24 hours during one week. Samples were first measured for $\mathrm{OD}_{600}$ and then fixed with formaldehyde (2\%, final concentration) before flow cytometry analysis. Twenty-five microliters of fixed bacterial suspension was diluted 10-fold in TE buffer (10 mM Tris, $1 \mathrm{mM}$ EDTA) and stained with 2.5 $\mu \mathrm{L}$ of SYBR Green I before counting bacterial cells with a BD FACSCalibur flow cytometer (15 mW at $488 \mathrm{~nm}$, Becton Dickinson, USA). Correspondences obtained were $1 \mathrm{AU}=5 \times 10^{8}$ 234 cell mL ${ }^{-1}$ for $\mathrm{CNI} 15,2.8 \times 10^{8}$ cell mL ${ }^{-1}$ for $\mathrm{CNI} 26,4.2 \times 10^{8}$ cell mL $\mathrm{m}^{-1}$ for $\mathrm{CNI} 28,5 \times 10^{8}$ cell $\mathrm{mL}^{-1}$ for CNI35 and $8,2 \times 10^{8}$ cell $\mathrm{mL}^{-1}$ for CNI52. 
Glyphosate and metabolites concentration: Glyphosate and AMPA concentrations were determined in triplicate from $1 \mathrm{~mL}$ of culture media following the method of Wang et al. (2016a) with some modifications. Briefly, standards of glyphosate and AMPA (0-100 $\mu \mathrm{M})$ prepared on MOPS ${ }^{\mathrm{CN}}$ liquid media and culture samples were derivatized with 9-fluorenylmethylchloroformate (FMOC-CI) and analysed by HPLC (Waters Inc., MA, U.S.A) coupled with a Diode Array Detector (DAD) detector set at $\lambda=265 \mathrm{~nm}$, and a reverse phase column (Phenomenex Kinetex EVO C18, $5 \mu \mathrm{m}, 150$ x $4.6 \mathrm{~mm}$ ) at $22{ }^{\circ} \mathrm{C}$. The mobile phase was made up of $5 \mathrm{mM}$ ammonium acetate $\mathrm{pH} 9$ (Solvent A) and methanol (Solvent B) at a flow rate of $1 \mathrm{~mL} \mathrm{m^{-1 }}$, linear gradient 0-5 min: $80 \% \mathrm{~A} ; 5-11 \mathrm{~min}: 80-30 \% \mathrm{~A} ; 11-$ 16 min: 30 \% A; 16-20 min: 30-80\% A; 20-30 min: $80 \%$ A. Glyphosate and AMPA were detected at 2.8 and 12.4 minutes retention time. Sample taken in triplicate were injected twice. Glyphosate and AMPA quantification in the strain's biomass was measured at the end of experiments following the method described in Carles et al. (2019).

Sarcosine, glycine and formaldehyde (MAK073-1KT, MAK261-1KT and MAK131$1 \mathrm{KT}$, respectively) concentrations were determined fluorometrically in triplicate from $1 \mathrm{~mL}$ of culture media using assay kits purchased from Sigma Aldrich and following the manufacturer's recommendations. Measurements were performed on a Spark 10M (Tecan, Switzerland) multimode microplate reader. Excitation/emission wavelengths were set up to $535 / 587 \mathrm{~nm}$ for sarcosine and glycine concentration determination and 370/470 $\mathrm{nm}$ for formaldehyde concentration determination. Glycine concentration was also determined in $\mathrm{K}_{2} \mathrm{HPO}_{4}$ and AMPA treatments as background control since glycine is a common metabolite produced by bacteria. The orthophosphate $\left(\mathrm{PO}_{4}{ }^{3-}\right)$ concentration was determined in triplicate from $1 \mathrm{~mL}$ of culture media using a spectrophotometer $\left(890 \mathrm{~nm}\right.$, Genesys ${ }^{\mathrm{TM}}$ 20, ThermoSpectronic, NY, USA) according to the protocol of Murphy and Riley (1962).

C-P lyase and glyphosate oxidase genes in CNI26: The genome of the strain CNI26 was sequenced and the diversity of C-P lyase and glyphosate oxidase genes was analysed to design specific primers for further gene expression experiments. The shotgun genomic library of CNI26 was prepared with the Hyper Library construction kit from Kapa Biosystems (Roche). The library was quantified by qPCR and sequenced on one MiSeq Micro flow cell for 251 cycles from each end of the fragments using a MiSeq 500-cycle sequencing kit version 2. The program used to perform de-novo genome assembly was Spades, version 3.11.1. The size of the assembly was $5.75 \mathrm{Mb}$ which means that the approx. genome coverage was $270 \times$. The assembly was fragmented in 89 scaffolds. We took the longest scaffold (700 
$\mathrm{kb}$ ) and compared it to the closest sequences retrieved in GenBank database using BLAST. The top hit was CP003872.1 Acidovorax sp. KKS102. The genome assembly was annotated with Prokka v 1.3. Annotation results reveal the presence of one glycine oxidase gene copy and two C-P lyase pathway-encoding operons including genes for: transport proteins (phnCDE), known enzymatic activity in phosphonate catabolism (phnIJMLN), auxiliary polypeptides involved in phosphonates catabolism (phnGHKL) (Hove-Jensen et al. 2014). The qPCR primers were specifically designed in this study for the strain Acidovorax sp. CNI26 using Primer3Plus (Untergasser et al. 2007). The primers used were CP-lyasesF (5'CCA CCC YTT TGA RGT GCA GC-3') and CP-lyasesR (5'-CCT GGC AAT AGT CSG AG-3') for the C-P lyase gene expression and GlyoxF (5'-CTA CAT CGC GCC CAA ACA AG-3') and GlyoxR (5' ATT GTG TGG CCA GCT CCA G 3') for glycine oxidase expression.

RT-qPCR analysis on glyphosate-degrading genes was performed using total RNA extracted from strain CNI26 exposed to glyphosate, AMPA and $\mathrm{K}_{2} \mathrm{HPO}_{4}$ as $\mathrm{P}$ source in triplicate. RNA samples were taken at the middle and the end of the exponential decay phases of glyphosate (100 and 124 hours) and AMPA (36 and 48 hours) dissipation curves observed in the previous biodegradation experiment. Five millilitres of the CNI26 bacterial culture were quickly sampled from each experimental condition, mixed with RNAlater® solution (1:1 v:v) and stored at $4{ }^{\circ} \mathrm{C}$ until RNA extraction. Before RNA extraction, bacteria were washed twice with 1X PBS. Total RNA was extracted according to the method described by Toledo-Arana et al. (2009). Briefly, bacteria were mechanically lysed with the PreCellys 24 system (Bertin Technologies, Montigny le Bretonneux, France) at a speed of $6.5 \mathrm{~m} \mathrm{~s}^{-1}$ for two consecutive cycles of $30 \mathrm{~s}$. After acid phenol and TRIzol ${ }^{\circledR}$ extraction, total RNA was precipitated with isopropanol and treated with 10 units of TURBO DNase. After a second phenol-chloroform extraction and ethanol precipitation, RNA pellets were suspended in DEPC-treated water. The efficiency of the DNase treatment was checked by PCR using the $16 \mathrm{~S}$ BAC338f/515r primers (Borrel et al. 2012). RNA concentration in the extracts was quantified with the Qubit system (Thermo Fisher Scientific). Extracted RNA was then converted into cDNA with the SuperScript III Reverse Transcriptase kit (Invitrogen, USA) using Random Primers (Invitrogen) and according to the manufacturer's instructions. qPCR was performed in a CFX96 touch Real-Time PCR detection system (BioRad, USA) using the MESA GREEN qPCR Master Mix Plus kit (Eurogentec) coupled with white qPCR96-well plates (Eurogentec) in a final volume of $15 \mu \mathrm{L}$ and using the C-P lyase and glycine oxidase primers described above. The qPCR conditions were as follows: initial denaturation at $95{ }^{\circ} \mathrm{C}$ for $5 \mathrm{~min}, 40$ 
cycles of denaturation at $95^{\circ} \mathrm{C}$ for $30 \mathrm{~s}$, primer annealing at $60{ }^{\circ} \mathrm{C}$ for $15 \mathrm{~s}$ and elongation at $72{ }^{\circ} \mathrm{C}$ for 20 s. C-P lyase and glycine oxidase gene expressions were normalized using the $16 \mathrm{~S}$ rRNA (BAC338f/515r) as the housekeeping gene.

\subsection{Data treatment and statistical analyses}

Bacterial growth during biodegradation experiments for each of the 5 isolated strains was fitted to the Gompertz growth model (SGompertz) according to the following equation:

$$
B t=\operatorname{Max} e^{-e^{(-m g(x-M a x 50))}}
$$

Where $B t$ is the bacterial density (in cells $\mathrm{mL}^{-1}$ ) at time $t$, Max is the maximum amplitude of the curve (cells $\mathrm{mL}^{-1}$ ), $\operatorname{Max}_{50}$ is the time required (hours) for bacterial density to increase 50 $\%$ of the initial value and $m_{g}$ is the growth rate coefficient (hours ${ }^{-1}$ ). Direct comparisons between treatments (glyphosate, AMPA) and control $\left(\mathrm{K}_{2} \mathrm{HPO}_{4}\right)$ for the $\mathrm{Max}_{50}$ parameter was achieved by the ratio $\mathrm{Max}_{50_{-}}$treatment/Max ${ }_{50}$ control calculation. A ratio value $<1$ indicates lower $\operatorname{Max}_{50}$ values in the treatment (faster growth) than in the control, whereas a ratio $>1$ indicates higher $\operatorname{Max}_{50}$ values in the treatment (slower growth) than in the control.

Dissipation kinetics of glyphosate, AMPA and $\mathrm{K}_{2} \mathrm{HPO}_{4}$ molecules in the media during biodegradation experiments were fitted to a dose-response sigmoidal model (DosResp), according to the following equation:

$$
C t=C f+\frac{C i-C f}{1+10^{(D T 50-x) m d}}
$$

where $C t$ is the molecule concentration $(\mu \mathrm{M})$ at time $t, C i$ the initial concentration of the molecule $(\mu \mathrm{M}), C f$ the final concentration of the molecule $(\mu \mathrm{M}), D T_{50}$ the time required to decrease the concentration of the molecule by $50 \%$ of its initial concentration value (hours) and $m_{d}$ the dissipation rate coefficient $\left(\right.$ hours $^{-1}$ ). Direct comparison between treatments (glyphosate and AMPA) and control $\left(\mathrm{K}_{2} \mathrm{HPO}_{4}\right)$ for the $D T_{50}$ parameter was achieved by the ratio $D T_{50}$ treatment $/ D T_{50}$ control calculation. A ratio $<1$ indicates lower $D T_{50}$ values in the treatment (faster dissipation) than in the control, whereas a ratio $>1$ indicates higher $D T_{50}$ values in the treatment (slower dissipation) than in the control. 
335 All fittings were performed using the OriginPro 2016 software (Origin Lab Corporation, 336 USA).

338 Statistical differences related to the bacterial growth kinetics parameters (Max, Max 50 and $m_{g}$ ) 339 or glyphosate, AMPA and $\mathrm{K}_{2} \mathrm{HPO}_{4}$ dissipation kinetics parameters $\left(D T_{50}\right.$ and $\left.m_{d}\right)$ among the 340 five isolated bacterial strains were assessed using multiple Kruskal-Wallis tests followed by 341 separate pairwise comparison tests using the Tukey's contrast. The factors tested were strain 342 (CNII15, CNI26, CNI28, CNI35 and CNI52), P-source (glyphosate, AMPA and $\mathrm{K}_{2} \mathrm{HPO}_{4}$ ) and 343 their interaction (strain $\times \mathrm{P}$ source).

344 C-P lyase and glyphosate oxidase gene expression was expressed as the relative quantity of 345 copies of genes in each of the P-source treatments (glyphosate, AMPA and $\mathrm{K}_{2} \mathrm{HPO}_{4}$ ) 346 following the model of Pfaffl (2001):

$$
\text { Relative quantity }=\frac{E^{-C q S 1 G i}}{E^{-C q S 1 G R}}
$$

349 where $E$ is the primer efficiency, $C q S i G i$ is the threshold cycle for the gene of interest (i.e. C350 P lyase or glycine oxidase) and CqSiGR is the threshold cycle for the housekeeping gene 351 (16S). Statistical differences between sampling times within glyphosate and AMPA 352 treatments were performed for each gene separately using the Kruskal-Wallis test.

353 All the statistical analyses were computed using the $\mathrm{R}$ software Version 4.0.3 at the alpha 354 threshold of 0.05 . 


\subsection{Bacterial growth and taxonomic affiliation}

360

361

362

363

364

365

366

367

368

369

370

371

372

373

374

375

376

377

378

379

380

381

382

383

384

385

386

387

388

389

390

Most of the strains were able to grow in the presence of $\mathrm{K}_{2} \mathrm{HPO}_{4}$, glyphosate or AMPA as unique $\mathrm{P}$ source, except CNII15 in the presence of glyphosate (Table 1, Figure S1). P treatments had a significant effect on the growth dynamics of bacterial strains; the lowest time required to increase bacterial density by $50 \%\left(M_{50}\right)$ was observed with $\mathrm{K}_{2} \mathrm{HPO}_{4}(48.3 \pm 5.3$ days on average for the 5 strains), followed by AMPA $(80.3 \pm 21.9$ days $)$ and glyphosate (168.1 \pm 37.9 days) (Kruskal-Wallis test, $P<0.001$; Table 2). $D T_{50} / D T_{50 \_K 2 H P O 4}$ ratio calculations confirmed the same trend; AMPA treatment displayed lower ratio values ranging from 0.95 to 1.49 (except CNII15, ratio $=4.32$ ) compared to the glyphosate treatment ranging from 2.22 to 4.61 (Table 1 ).

Strain growth also varied within $\mathrm{P}$ treatments (Strain $\times \mathrm{P}$ treatment, Table 2). According to the $\operatorname{Max}_{50}$ results, strain CNI28 grew faster in the presence of $\mathrm{K}_{2} \mathrm{HPO}_{4}$, strains CNI26 and CNI28 grew faster in the presence of AMPA, and finally, strain CNI26 grew faster in the presence of glyphosate (Tukey's test, $P<0.05$; Table 1). Maximal bacterial density (Max) was not different among $\mathrm{P}$ treatments $(P=0.44)$, although an interaction effect existed between strains and $\mathrm{P}$ treatments (Table 2). Comparatively, the highest Max values in the presence of $\mathrm{K}_{2} \mathrm{HPO}_{4}$, AMPA and glyphosate were observed for strains CNI35, CNII15 and CNI52, respectively (Tukey's test, $P<0.05$; Table 1). No statistical differences were observed for growth rates $\left(m_{g}\right)$ among $\mathrm{P}$ treatments $(P=0.10)$ but strain $\mathrm{x} \mathrm{P}$ treatment interaction existed for $\mathrm{K}_{2} \mathrm{HPO}_{4}$ and AMPA $(P<0.05$ both, Table 2$)$. The highest $m_{g}$ values in the presence of $\mathrm{K}_{2} \mathrm{HPO}_{4}$ and AMPA were observed for CNI52 and CNI28, respectively (Table 1). The strong variability of $m_{g}$ values among strains in the presence of glyphosate resulted in non-statistical differences.

Four out of the five isolated strains showed an affiliation with $\alpha$-proteobacteria: Ensifer sp. (CNII15), Agrobacterium tumefaciens (CNI28), Novosphingobium sp. (CNI35) and Ochrobactrum pituitosum (CNI52), whereas only one showed affiliation with $\beta$ proteobacteria: Acidovorax sp. (CNI26) (Figure 2). The majority of known glyphosatedegrading strains in $\alpha$ - and $\beta$-proteobacteria use glyphosate as the source of $\mathrm{P}$, whereas few exceptions use the herbicide as the source of $\mathrm{C}$ (Agrobacterium tumefaciens P5 and Achromobacter sp. CH1, Figure 2). 
391 Figure 2. Phylogenetic analysis of the five bacterial strains isolated from stream biofilms, together with the known bacterial glyphosate-degrading strains based on $16 \mathrm{~S}$ gene sequence

393 (Table S1). Only one sequence per genus has been included in the present analysis, either the 394 16S rDNA gene sequence of the glyphosate-degrading strain described, or the sequence of a corresponding genus/species if the degrading strain sequence was not available (NA). The alignment was performed with ClustalW. The tree was constructed with the Neighbor-Joining $397(\mathrm{~N}=1000$ bootstrap replicates $)$ using MEGA6. Scale bar $=0.05$ substitution per site. 398 Bootstrap percentages $\geq 50 \%$ are indicated near tree nodes. For the glyphosate-degrading 399 strains, the metabolism of glyphosate (source of carbon $(\mathrm{C})$, nitrogen $(\mathrm{N})$ and phosphorus $(\mathrm{P})$ ) and the main metabolite (AMPA (A), Sarcosine (S), formaldehyde (F), glycine (G) or unknown (U)) are also indicated on the right.

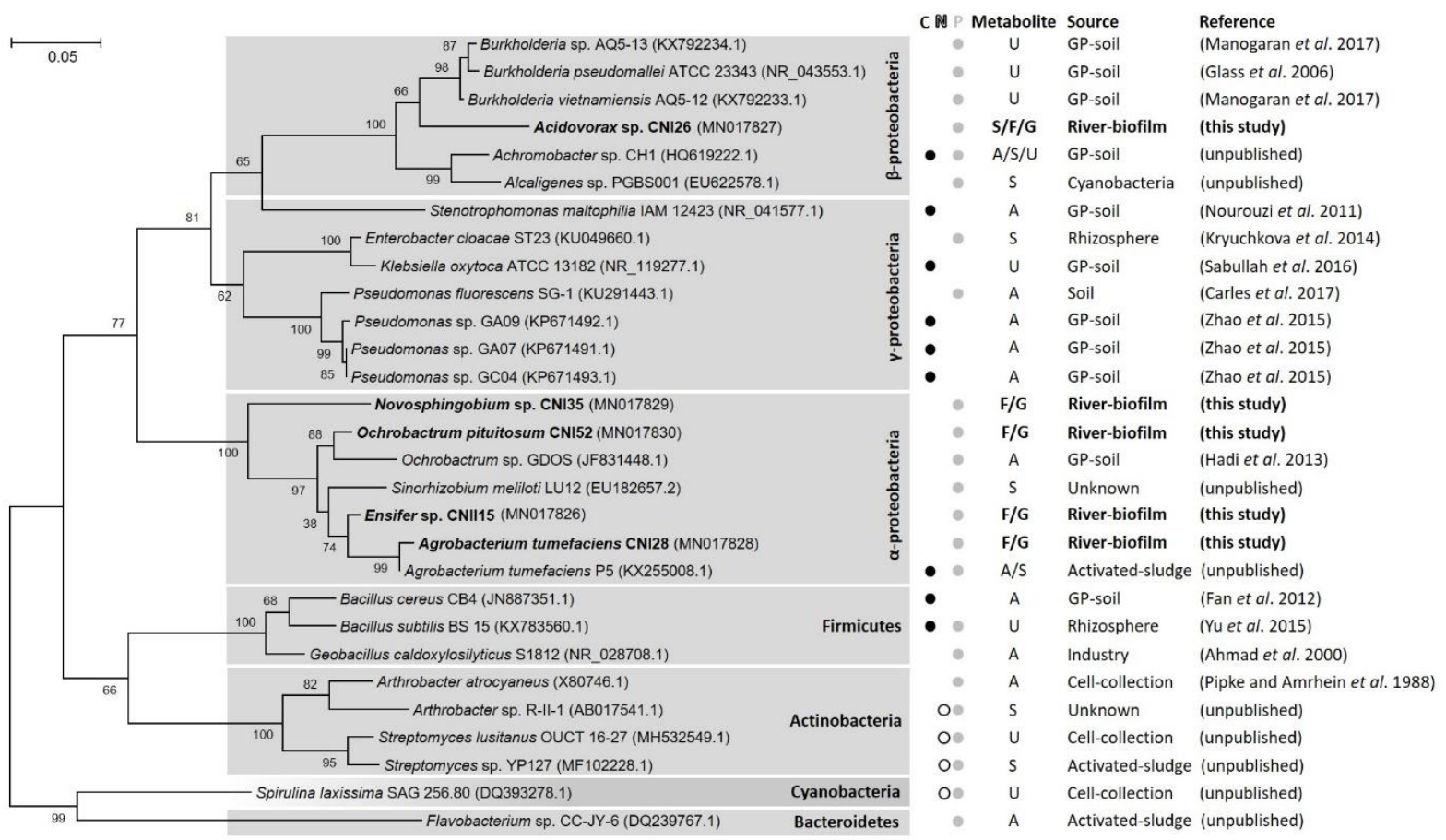


Table 1. Microbial growth estimated parameters $\left(\operatorname{Max}, \operatorname{Max}_{50}, m_{g}\right)$ and model fitting (R-square) are represented for each microbial strain subjected to glyphosate, AMPA and Phosphorus (control) treatments. Pairwise comparisons tests (Tukey's contrast, $P<0.05$ ) on growth parameters were run between (uppercase letters) and within (lowercase letters) treatments. N.S means not statistically significant and N.D means that data did not fit the dose-response sigmoidal model.

\begin{tabular}{|c|c|c|c|c|c|c|c|c|c|c|c|}
\hline & Strain & Growth model pa & leters & & & & & & & & \\
\hline & & $\operatorname{Max}\left(\right.$ Cell $\left.\mathrm{mL}^{-1}\right)$ & & & $\operatorname{Max}_{50}\left(\right.$ Hours $\left.^{-1}\right)$ & & & $m_{g}\left(\right.$ Hours $\left.^{-1}\right)$ & & $\mathrm{R}^{2}$ & $\operatorname{Max}_{50} / \operatorname{Max}_{50_{-}} \mathrm{K}_{2} \mathrm{HPO}_{4}$ \\
\hline \multirow{5}{*}{$\mathrm{K}_{2} \mathrm{HPO}_{4}$} & CNII15 & $6.22 \mathrm{E} 8 \pm 7.57 \mathrm{E} 7$ & (b) & & $38.50 \pm 0.13$ & (d) & \multirow{5}{*}{ (C) } & $0.075 \pm 0.003$ & (c) & $0.992 \pm 0.002$ & 1 \\
\hline & CNI26 & $2.00 \mathrm{E} 8 \pm 6.21 \mathrm{E} 6$ & (e) & & $45.17 \pm 0.78$ & (c) & & $0.048 \pm 0.003$ & (d) & $0.996 \pm 0.001$ & 1 \\
\hline & $\mathrm{CNI} 28$ & $4.26 \mathrm{E} 8 \pm 3.80 \mathrm{E} 6$ & (d) & & $36.79 \pm 1.21$ & (e) & & $0.107 \pm 0.011$ & (a) & $0.993 \pm 0.001$ & 1 \\
\hline & CNI35 & $6.76 \mathrm{E} 8 \pm 1.13 \mathrm{E} 7$ & (a) & & $63.97 \pm 0.72$ & (a) & & $0.088 \pm 0.002$ & (b) & $0.954 \pm 0.011$ & 1 \\
\hline & CNI52 & $4.95 \mathrm{E} 8 \pm 2.30 \mathrm{E} 7$ & (b) & & $57.16 \pm 0.39$ & (b) & & $0.114 \pm 0.013$ & (ab) & $0.867 \pm 0.017$ & 1 \\
\hline \multirow{5}{*}{ AMPA } & CNII15 & $6.59 \mathrm{E} 8 \pm 1.50 \mathrm{E} 7$ & (a) & & $159.11 \pm 1.45$ & (a) & & $0.037 \pm 0.002$ & \multirow{5}{*}{$(\mathrm{N} . \mathrm{S})$} & $0.992 \pm 0.003$ & $4.32 \pm 0.02$ \\
\hline & $\mathrm{CNI} 26$ & $2.34 \mathrm{E} 8 \pm 1.56 \mathrm{E} 6$ & (d) & & $42.91 \pm 0.30$ & (d) & & $0.050 \pm 0.002$ & & $0.993 \pm 0.001$ & $0.95 \pm 0.02$ \\
\hline & $\mathrm{CNI} 28$ & $4.20 \mathrm{E} 8 \pm 5.59 \mathrm{E} 6$ & (c) & (N.S) & $43.60 \pm 0.66$ & (d) & (B) & $0.107 \pm 0.011$ & & $0.979 \pm 0.006$ & $1.19 \pm 0.06$ \\
\hline & CNI35 & $5.14 \mathrm{E} 8 \pm 1.14 \mathrm{E} 7$ & (b) & & $95.73 \pm 1.74$ & (b) & & $0.097 \pm 0.005$ & & $0.992 \pm 0.004$ & $1.49 \pm 0.04$ \\
\hline & CNI52 & $5.64 \mathrm{E} 8 \pm 3.69 \mathrm{E} 7$ & $(a b)$ & & $60.06 \pm 0.47$ & (c) & & $0.099 \pm 0.019$ & & $0.957 \pm 0.014$ & $1.05 \pm 0.01$ \\
\hline \multirow{5}{*}{ Glyphosate } & CNII15 & N.D & & & N.D & & \multirow{5}{*}{ (A) } & N.D & \multirow{5}{*}{ (N.S) } & N.D & N.D \\
\hline & CNI26 & $9.21 \mathrm{E} 7 \pm 2.15 \mathrm{E} 6$ & (c) & & $116.53 \pm 2.62$ & (c) & & $0.111 \pm 0.017$ & & $0.988 \pm 0.001$ & $2.58 \pm 0.03$ \\
\hline & CNI28 & $3.99 \mathrm{E} 8 \pm 4.27 \mathrm{E} 7$ & (b) & & $134.58 \pm 10.42$ & (b) & & $0.015 \pm 0.002$ & & $0.973 \pm 0.004$ & $3.66 \pm 0.24$ \\
\hline & CNI35 & $5.48 \mathrm{E} 8 \pm 2.88 \mathrm{E} 7$ & $(a b)$ & & $294.58 \pm 25.68$ & (a) & & $0.066 \pm 0.046$ & & $0.996 \pm 0.002$ & $4.61 \pm 0.42$ \\
\hline & CNI52 & $5.59 \mathrm{E} 8 \pm 7.70 \mathrm{E} 7$ & (a) & & $126.65 \pm 2.56$ & (b) & & $0.041 \pm 0.004$ & & $0.981 \pm 0.001$ & $2.22 \pm 0.06$ \\
\hline
\end{tabular}


Table 2. Results of the Kruskal-Wallis tests performed on bacterial growth model parameters (Max, $\operatorname{Max}_{50}$ and $m_{g}$ ) and dissipation model

411 parameters $\left(D T_{50}\right.$ and $\left.k_{d}\right)$. The tested factors are $\mathrm{P}$ treatments $\left(\mathrm{K}_{2} \mathrm{HPO}_{4}, \mathrm{AMPA}\right.$ or glyphosate) and the interaction between strains $(\mathrm{CNII} 15$, 412 CNI26, CNI28, CNI35, CNI52) and P treatments. $X^{2}$ statistic scores, degrees of freedom (Df) and $P$-values were provided for each source of variation. Bold values indicate significant differences at $P<0.05$.

414

\begin{tabular}{|c|c|c|c|c|c|c|c|c|c|c|c|c|c|c|c|c|}
\hline \multicolumn{2}{|c|}{ Kruskal-Wallis } & \multicolumn{6}{|c|}{ Dissipation model parameters } & \multicolumn{9}{|c|}{ Growth model paraemters } \\
\hline \multirow{2}{*}{\multicolumn{2}{|c|}{ Testedfactors }} & $m_{d}$ & & & $D T_{50}$ & & & $m_{g}$ & & & $\operatorname{Max}_{50}$ & & & $\operatorname{Max}$ & & \\
\hline & & $X^{2}$ & $D f$ & $p$ value & $X^{2}$ & $D f$ & $p$ value & $X^{2}$ & $D f$ & $p$ value & $X^{2}$ & $D f$ & $p$ value & $X^{2}$ & $D f$ & $p$ value \\
\hline \multirow[t]{2}{*}{ P source } & & 22.88 & 2 & $<0.001$ & 22.19 & 2 & $<0.001$ & 4.54 & 2 & 0.10 & 21.77 & 2 & $<0.001$ & 1.61 & 2 & 0.44 \\
\hline & $\mathrm{K}_{2} \mathrm{HPO}_{4}$ & 12 & 4 & $<0.05$ & 12.9 & 4 & $<0.05$ & 12.4 & 4 & $<0.05$ & 13.5 & 4 & $<0.01$ & 13.5 & 4 & $<0.01$ \\
\hline \multirow[t]{2}{*}{ Strain $x$} & AMPA & 12.63 & 4 & $<0.05$ & 12.9 & 4 & $<0.05$ & 10.9 & 4 & $<0.05$ & 13.03 & 4 & $<0.05$ & 12.7 & 4 & $<0.05$ \\
\hline & Gly & 8.64 & 3 & $<0.05$ & 6.58 & 3 & 0.08 & 6.89 & 3 & 0.07 & 9.35 & 3 & $<0.05$ & 8.69 & 3 & $<0.05$ \\
\hline
\end{tabular}


Initial concentrations in P-equivalents of $\mathrm{K}_{2} \mathrm{HPO}_{4}$, AMPA and glyphosate averaged $117.1 \pm$ $4.3 \mu \mathrm{M}\left(C_{i}\right)$ and final concentrations dropped to $0 \mu \mathrm{M}\left(C_{f}\right)$ for all $\mathrm{P}$ treatments and strains (Table 3). Accumulation of glyphosate and/or AMPA in strain biomass at the end of experiments was $<0.5 \%$ of the initial amount of glyphosate and/or AMPA added. All the strains were able to use either of the above-mentioned compounds as sole $\mathrm{P}$ source, except CNII15, which was not able to use glyphosate (Figure 3). However, differences in dissipation kinetics between $\mathrm{P}$ treatments as well as among strains $\mathrm{x}$ P treatments were observed (Table 2). Average $D T_{50}$ values for $\mathrm{K}_{2} \mathrm{HPO}_{4}$ and AMPA $(34.8 \pm 5.7$ and $67.4 \pm 22.1$ hours, respectively) were higher compared to that of glyphosate (165.1 \pm 46.2 hours; Tukey's test, $P$ $<0.05$; Table 3). This was confirmed by $D T_{50} / D T_{50 \_K 2 H P O 4}$ ratio calculations which displayed average ratio values ranging from 1.02 to 1.85 for AMPA and 2.22 to 6.60 for glyphosate. Dissipation rates $\left(m_{d}\right)$ were also higher for $\mathrm{K}_{2} \mathrm{HPO}_{4}\left(0.53 \pm 0.21\right.$ hours $\left.{ }^{-1}\right)$ and AMPA $(0.29 \pm$ 0.12 hours $\left.^{-1}\right)$ compared to glyphosate $\left(0.04 \pm 0.01\right.$ hours $\left.^{-1}\right)$ (Tukey's test, $P<0.05$; Table 3). The CNII15 strain was the only exception for slow AMPA dissipation reaching a $D T_{50} / D T_{50 \_K 2 H P O 4}$ ratio of 5.12 and $m_{d}$ of $0.05 \pm 0.018$ hours $^{-1}$.

The strain $\mathrm{x} \mathrm{P}$ treatment interaction on the $D T_{50}$ parameter revealed faster AMPA dissipation by CNI26 and CNI28 strains (Tukey's test, $P<0.05$ ) and faster glyphosate dissipation by CNI26 and CNI52 strains, although not statistically significant $(P>0.05$, Table 3). Dissipation rates $\left(m_{d}\right)$ differed between strains in the same manner that $D T_{50}$ did. For instance, the highest AMPA dissipation rates were found in CNI26 and CNI28 (0.662 and 0.464 hours $^{-1}$, respectively) while the highest glyphosate dissipation rates were found in CNI26 and CNI52 (0.055 and 0.056 hours $^{-1}$, respectively) (Tukey's test, $P<0.05$ ).

.

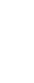


450 Figure 3. Dissipation kinetics of $\mathrm{K}_{2} \mathrm{HPO}_{4}$ (A), AMPA (B) and glyphosate (C) for the five 451 bacterial strains (CNII15, CNI26, CNI28, CNI35, CNI52). Fittings to the dose-response 452 sigmoidal model (DosResp) are represented. Lines correspond to the model with mean 453 parameters values for each condition. The values are means \pm standard errors $(n=3)$ of the 454 experimental data.

455
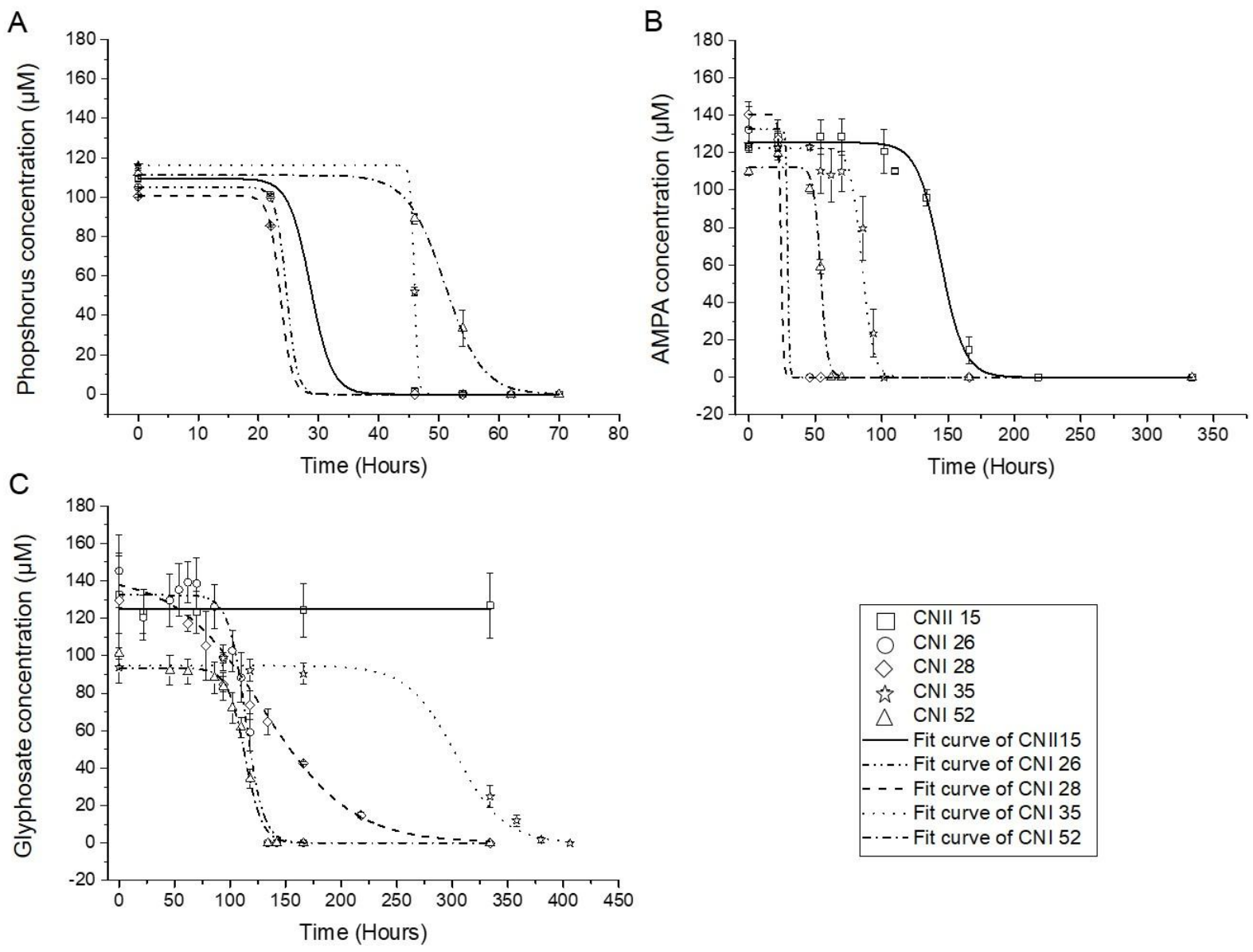

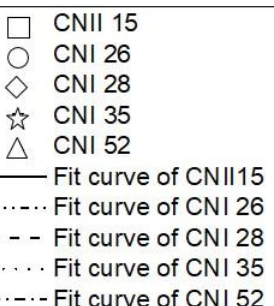


Table 3. Kinetics of $\mathrm{K}_{2} \mathrm{HPO}_{4}$, AMPA and glyphosate dissipation for each bacterial strain analyzed (CNII15, CNI26, CNI28, CNI35, CNI52). Values of the model parameters are final concentration $(C f)$, initial concentration $(C i)$, dissipation time $50 \%\left(D T_{50}\right)$, dissipation rate $\left(m_{d}\right)$ and coefficient of determination $\left(\mathrm{R}^{2}\right)$ are reported as the mean \pm standard error. Statistical differences between $\mathrm{P}$ treatments $\left(\mathrm{K}_{2} \mathrm{HPO}{ }_{4}\right.$, AMPA or glyphosate) are indicated by the uppercase letters (A > B > C, Tukey's test, $P<0.05)$ whereas statistical differences between strains are indicated by the lowercase letters $(\mathrm{a}>\mathrm{b}>\mathrm{c}>\mathrm{d}$, Tukey's test, $\mathrm{P}<0.05)$. N.S means not statistically significant and N.D: no fittingto dose-response sigmoidal model.

\begin{tabular}{|c|c|c|c|c|c|c|c|c|c|c|c|}
\hline & Strain & Dissipati & model paramete & & & & & & & & \\
\hline & & $C f(\mu \mathrm{M})$ & $C i(\mu \mathrm{M})$ & $D T_{50}\left(\right.$ Hours $\left.^{-1}\right)$ & & & $m_{d}\left(\right.$ Hours $\left.^{-1}\right)$ & & & $\mathrm{R}^{2}$ & $D T_{50} / D T_{50} \mathrm{~K}_{2} \mathrm{HPO}_{4}$ \\
\hline \multirow{5}{*}{$\mathrm{K}_{2} \mathrm{HPO}_{4}$} & CNII15 & $0 \pm 0$ & $109.44 \pm 1.34$ & $28.64 \pm 2.50$ & (c) & \multirow{5}{*}{ (B) } & $0.242 \pm 0.114$ & $(a b)$ & \multirow{5}{*}{ (B) } & $0.999 \pm 0.001$ & 1 \\
\hline & CNI26 & $0 \pm 0$ & $105.01 \pm 0.61$ & $24.65 \pm 0.02$ & (c) & & $0.486 \pm 0.003$ & (c) & & $1 \pm 0$ & 1 \\
\hline & CNI28 & $0 \pm 0$ & $100.67 \pm 0.70$ & $23.65 \pm 0.02$ & (d) & & $0.455 \pm 0.002$ & (b) & & $1 \pm 0$ & 1 \\
\hline & CNI35 & $0 \pm 0$ & $116.24 \pm 0.26$ & $45.93 \pm 0.03$ & (b) & & $1.342 \pm 0.033$ & (d) & & $1 \pm 0$ & 1 \\
\hline & CNI52 & $0 \pm 0$ & $111.20 \pm 2.11$ & $51.03 \pm 1.22$ & (a) & & $0.139 \pm 0.005$ & (a) & & $0.994 \pm 0.004$ & 1 \\
\hline \multirow{5}{*}{ AMPA } & CNII15 & $0 \pm 0$ & $125.36 \pm 7.71$ & $144.41 \pm 1.22$ & (a) & \multirow{5}{*}{ (B) } & $0.049 \pm 0.019$ & (a) & \multirow{5}{*}{ (B) } & $0.987 \pm 0.008$ & $5.12 \pm 0.47$ \\
\hline & CNI26 & $0 \pm 0$ & $132.55 \pm 14.65$ & $29.29 \pm 5.17$ & (d) & & $0.662 \pm 0.196$ & (c) & & $0.999 \pm 0.001$ & $1.18 \pm 0.21$ \\
\hline & CNI28 & $0 \pm 0$ & $140.37 \pm 6.93$ & $24.15 \pm 0.15$ & (d) & & $0.464 \pm 0.005$ & (c) & & $1 \pm 0$ & $1.02 \pm 0.01$ \\
\hline & CNI35 & $0 \pm 0$ & $122.32 \pm 0.76$ & $85.16 \pm 5.61$ & (b) & & $0.099 \pm 0.031$ & (a) & & $0.972 \pm 0.026$ & $1.85 \pm 0.12$ \\
\hline & CNI52 & $0 \pm 0$ & $112.19 \pm 1.43$ & $53.99 \pm 0.39$ & (c) & & $0.165 \pm 0.018$ & (b) & & $0.991 \pm 0.001$ & $1.06 \pm 0.02$ \\
\hline \multirow{5}{*}{ Glyphosate } & CNII15 & N.D & N.D & N.D & \multirow{5}{*}{ (N.S) } & \multirow{5}{*}{ (A) } & N.D & & \multirow{5}{*}{ (A) } & N.D & N.D \\
\hline & CNI26 & $0 \pm 0$ & $132.40 \pm 16.76$ & $114.14 \pm 2.89$ & & & $0.055 \pm 0.009$ & (b) & & $0.945 \pm 0.024$ & $4.63 \pm 0.12$ \\
\hline & CNI28 & $0 \pm 0$ & $142.96 \pm 34.15$ & $129.76 \pm 22.53$ & & & $0.011 \pm 0.001$ & (a) & & $0.952 \pm 0.014$ & $5.49 \pm 0.96$ \\
\hline & CNI35 & $0 \pm 0$ & $94.69 \pm 6.19$ & $303.32 \pm 18.56$ & & & $0.020 \pm 0.004$ & (a) & & $0.989 \pm 0.009$ & $6.60 \pm 0.40$ \\
\hline & CNI52 & $0 \pm 0$ & $93.34 \pm 5.85$ & $113.33 \pm 1.13$ & & & $0.056 \pm 0.005$ & (b) & & $0.985 \pm 0.008$ & $2.22 \pm 0.04$ \\
\hline
\end{tabular}




\subsection{Metabolite production}

In the glyphosate treatment, no AMPA accumulation was observed but varying concentrations of formaldehyde, glycine and sarcosine were detected depending on the strain tested (Figure 4A). Sarcosine was only detected in strain CNI26 at $19 \%$ and $23 \%$ of mass balance calculations at the intermediate and final sampling times. Accumulation of formaldehyde at intermediate and final sampling times (5.3\% and $14 \%$, respectively), and glycine in much lower concentrations ( $2.0 \%$ and $2.4 \%$, respectively), were also observed in the CNI26 strain. The metabolite production pattern was rather similar among CNI28, CNI35 and CNI52, accumulating more formaldehyde on average (13.8\% on average for the three strains) than glycine $(3.2 \%)$ at the final sampling time. As described above, metabolite production was negligible for CNII15 subjected to glyphosate since no dissipation was observed (Figure 4A).

In the AMPA treatment, all AMPA was transformed and few metabolites accumulated at the end of the experiment. Metabolites, mostly formaldehyde, were detected at the final sampling time in CNI15, CNI26 and CNI52 (1.16\% on average for the three strains, Figure 4B), whereas strains CNI28 and CNI35 accumulated both glycine (2.6\%) and formaldehyde $(7.8 \%)$ at the final sampling time.

Figure 4. Mass balance of glyphosate and metabolites in the glyphosate (A) and AMPA (B) treatments at initial (0 hours; I), intermediate (1/2 dissipation of glyphosate/AMPA; M) and final (complete dissipation of glyphosate/AMPA; F) times for the five bacterial strains.

Glyphosate (A)

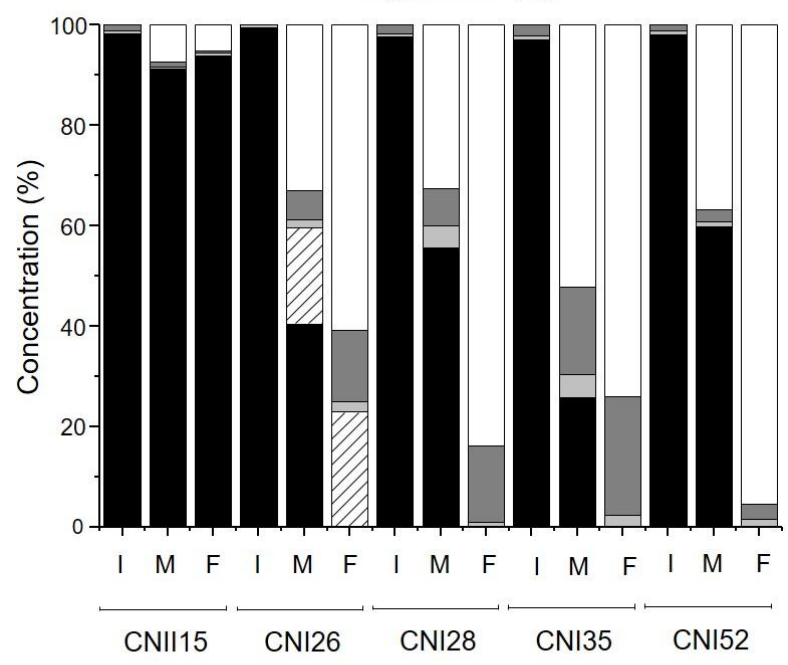

AMPA (B)

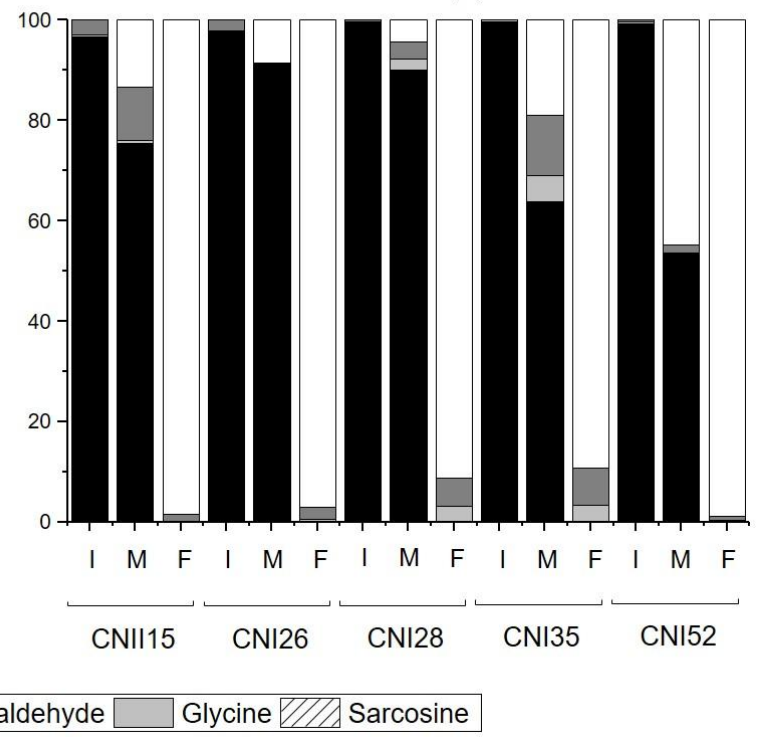


A detailed analysis on metabolite formation by the CNI26 strain subjected to $\mathrm{K}_{2} \mathrm{HPO}_{4}$ and

491

492

493

494

495

496

497

498

499

500

501

502

503

504

505

506

507

508

509

510

511

512

513

514

515

516

517

518

519

520

AMPA treatments revealed stable and quite low concentrations of sarcosine and glycine throughout the experiment $(<10 \mu \mathrm{M}$, Figure 5A and B). Formaldehyde concentrations were below the limit of detection regardless of the treatment which contradicts the results obtained in section 3.3, where formaldehyde reached $14 \%$ of mass balance calculations at the final sampling time for CNI26 (Figure 4). In the glyphosate treatment (Figure 5C), sarcosine production was observed along with the dissipation of glyphosate to reach a concentration value of $185 \pm 0.6 \mu \mathrm{M}$ after 168 hours of experiment, close to the initial glyphosate concentration supplied. The sarcosine results coincide with those described in section 3.3 for CNI26 and are in keeping with observations made for known $\beta$-proteobacteria glyphosatedegrading strains in the literature (Figure 2).

The relative quantity of C-P lyase and glyphosate oxidase genes (corrected by the 16S rRNA gene) varied among P treatments. Both C-P lyase and the glyphosate oxidase genes increased their expression between $36 \mathrm{~h}$ and $48 \mathrm{~h}$ in the $\mathrm{K}_{2} \mathrm{HPO}_{4}$ treatment and between $100 \mathrm{~h}$ and $124 \mathrm{~h}$ in the glyphosate treatment (Kruskal-Wallis test, $P<0.05$; Figure 5D and F), although this increase was greater in the presence of glyphosate (30X in average) than in the presence of $\mathrm{K}_{2} \mathrm{HPO}_{4}(10 \mathrm{X}$ in average). The opposite trend was observed in the case of the AMPA treatment. The expression of C-P lyase and glyphosate oxidase was overall greater at $36 \mathrm{~h}$ than at $48 \mathrm{~h}$, although this difference was only statistically significant for the glyphosate oxidase gene $(P<0.05)$. The expression of C-P lyase at $36 \mathrm{~h}$ in the AMPA treatment was extremely variable (Figure 5E). 
Figure 5. Kinetics of $\mathrm{K}_{2} \mathrm{HPO}_{4}$ (A) AMPA (B) or glyphosate (C) dissipation along with metabolites formation (sarcosine, glycine and AMPA) for the CNI26 strain in the culture media exposed to either $\mathrm{K}_{2} \mathrm{HPO}_{4}$, AMPA or glyphosate. The values are means \pm standard errors $(n=3)$ of the experimental data. The black rectangle highlights the times at which $\mathrm{C}-\mathrm{P}$ lyases (grey filled) and glycine oxidase (white filled) genes relative quantities were measured in the culture media exposed to either $\mathrm{K}_{2} \mathrm{HPO}_{4}(\mathrm{D})$, AMPA (E) or glyphosate (F). Asterisks indicate significant differences in genes relative expression (Kruskal-Wallis test, $P<0.05$ ).

$\mathrm{K}_{2} \mathrm{HPO}_{4}$
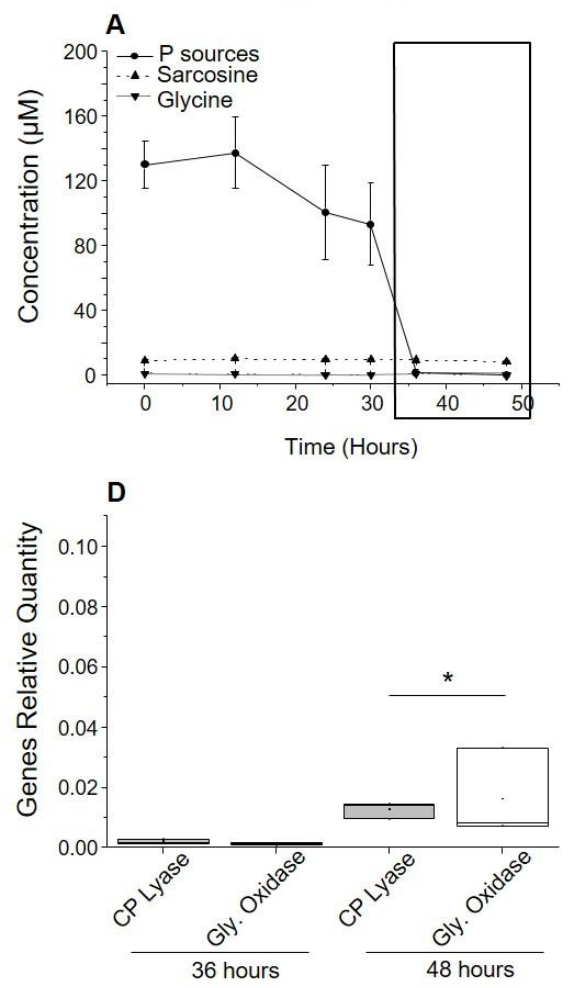

AMPA
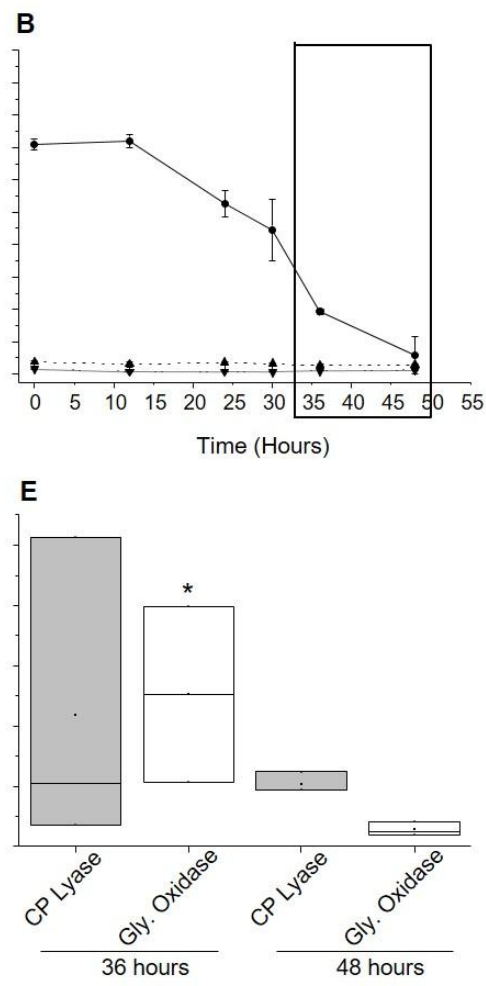

Glyphosate
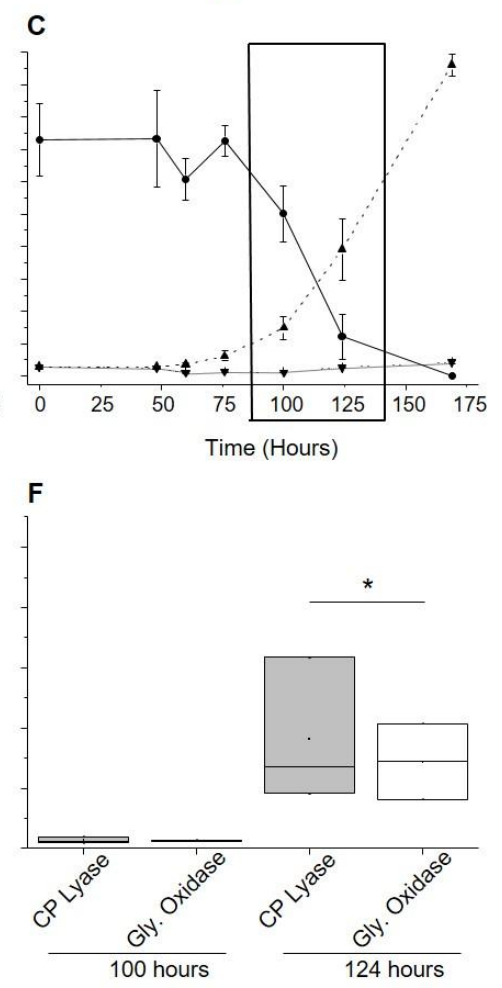

\section{DISCUSSION}

533 Four out of the five bacterial strains (Acidovorax sp. CNI26, Agrobacterium tumefaciens 534 CNI28, Novosphingobium sp. CNI35 and Ochrobactrum pituitosum CNI52) isolated from stream biofilms were able to completely dissipate AMPA between 30 to 120 hours and glyphosate between 125 to 400 hours when no alternative $\mathrm{P}$ source was available. These results are consistent with the literature as the utilization of glyphosate and AMPA as P 
sources have been reported as the most common metabolic pathway within bacteria in various environments (including soils, rhizosphere, and industrial effluents or activated sludge; Table S1). For instance, 23 out of 29 strains isolated metabolized glyphosate as P source, against 9 strains as $\mathrm{C}$ source and 4 strains as $\mathrm{N}$ source (Figure 2). Such generalized use of glyphosate and/or AMPA as P source could be explained by the widespread presence of the C-P lyase enzyme system encoded by the phn operon in bacteria (Hove-Jensen et al. 2014) which is responsible for $\mathrm{C}-\mathrm{P}$ bond cleavage and inorganic phosphorus $(\mathrm{Pi})$ transport and assimilation by cells (Chen et al. 1990, Stosiek et al. 2019). The only exception in our study was strain CNII15 which was not able to degrade glyphosate but completely dissipated AMPA in 200 hours. Indeed, the strain (Ensifer sp.CNII15) was neither capable to dissipate nor to grow on glyphosate suggesting: i) lack of adequate enzymatic machinery to metabolize glyphosate despite being able to metabolize AMPA, or ii) slow growth dynamics in the presence of glyphosate within 330 hours. It must be noted that the start of growth for CNII15 in the glyphosate treatment $\left(\mathrm{OD}_{600}=0.18\right)$ was observed at 334 hours (Rossi F. personal observation), without glyphosate dissipation, reinforcing the validity of our second hypothesis. When linking the 5 bacterial strains to their environmental origin, four out of the five strains (CNI26, CNI28, CNI35 and CNI52) were isolated from P-poor biofilms from an upstream section of the Artière River, whereas CNII15 was isolated from a P-rich biofilm from the downstream section of the same river (Carles et al. 2019). Since the Artière River is characterized by a strong gradient of pesticide contamination between its upstream and downstream sections (including glyphosate and AMPA, Rossi et al. 2019), the specific AMPA metabolism of CNII15 may result from site-adaptation mechanisms. For instance, Ensifer sp. CNII 15 could benefit from AMPA, which may result from glyphosate biodegradation by other microorganisms in biofilms such as the four other bacterial strains studied.

Dissipation was faster overall for AMPA than for glyphosate as suggested in our initial hypothesis. As expected, the time required for glyphosate/AMPA concentrations to decline $50 \%\left(D T_{50}\right)$ was closely related to the time required for the bacterial density to reach $50 \%$ increase $\left(\operatorname{Max}_{50}\right)$. The AMPA treatment showed lower values of both $D T_{50}$ and $M a x_{50}$ compared to the glyphosate treatment. These results are consistent with the literature, since AMPA was already reported as an easier substrate for degradation compared to glyphosate. The review of Hove-Jensen et al. (2014) reported that among a total of 133 environmental bacterial strains isolated from glyphosate-treated as well as non-treated soil, 26 strains were able to utilize glyphosate as a $\mathrm{P}$ source while 55 strains were capable to use AMPA as $\mathrm{P}$ 
source. The remaining 52 strains were able to degrade neither glyphosate nor AMPA. Hence, the faster dissipation of AMPA over glyphosate can likely be explained by i) a greater affinity of C-P lyase enzymes for AMPA than glyphosate molecules (Hove-Jensen et al. 2014), ii) low affinity of glyphosate oxidase for glyphosate (Pedotti et al. 2009), or iii) a purely chemical difference between glyphosate and AMPA, the latter being less complex and consequently being much more easily cleaved to release P. The molecular analysis of Acidovorax sp. CNI26 revealed that the highest expression of glycine oxidase and CP-lyase genes was observed before reaching $\operatorname{Max}_{50}$ in the presence of AMPA suggesting a decoupling between the expression of these genes and the increase of bacterial density. In contrast, the expression of glycine oxidase and CP-lyase genes was higher after reaching $\operatorname{Max}_{50}$ in the presence of glyphosate, hypothesizing that the degrading gene expression and their activity could be linked to the bacterial cell number. Moreover, the faster dissipation of AMPA is favoured by the lower toxicity for aquatic microorganisms of AMPA compared to glyphosate (Bonnet et al. 2007).

Differences in AMPA and glyphosate dissipation were observed among the five tested strains. The fastest AMPA dissipation $\left(D T_{50}\right)$ was found for CNI26 and CNI28 (29 and 24 hours, respectively), while the fastest dissipation for glyphosate was found for CNI26 and CNI52 (114 and 113 hours, respectively). To our knowledge, our study describes for the first time the ability of the Acidovorax genus (Acidovorax sp. CNI26) to dissipate both glyphosate and AMPA. The genome sequencing of Acidovorax sp. CNI26 revealed the presence of one glycine oxidase gene copy and two copies of the phn operon. A study reveals that bacterial glycine oxidase is capable to efficiently cleave glyphosate, producing AMPA and glyoxylate (Pedotti et al. 2009). Sviridov et al. (2015) speculate that there exists a whole range of bacterial flavin oxidases differing in structure, substrate specificity, and the extent of mutual homology, which can be generically termed glyphosate oxidoreductases (referring to their ability to oxidize glyphosate). Besides, the phn operon encodes transport proteins, phosphonate catabolism enzymes and auxiliary polypeptides involved in phosphonate catabolism, among others. Within this operon, seven genes $(p h n \mathrm{G}, p h n \mathrm{H}, p h n \mathrm{I}, p h n \mathrm{~J}, p h n \mathrm{~K}$, $p h n \mathrm{~L}$ and $p h n \mathrm{M})$ are supposed to encode the core components of the membrane-bound C-P lyase, metabolizing phosphonates to phosphate by PhnJ catalyst (Metcalf and Wanner 1993). Both glycine oxidase and $p h n \mathrm{G}$ to $\mathrm{M}$ genes confer to Acidovorax sp. CNI26 the potential to metabolize glyphosate either through the C-P lyase or the glyphosate oxidase degradation pathways. The genome analysis of several Agrobacterium species (including Agrobacterium vitis $\mathrm{S} 4$, A. tumefaciens strain $\mathrm{C} 58$, A. radiobacter $\mathrm{K} 84$ ) revealed identical phn gene orders 
conferring the potential to use a variety of phosphonates as $\mathrm{P}$ sources (Hove-Jensen et al. 2014). Similarly, Ochrobactrum species (i. e. O. anthropi strain GPK3) phylogenetically close to Ochrobactrum pituitosum CNI52 have also been shown able to grow with glyphosate as $\mathrm{P}$ source. Both the C-P lyase and the glyphosate oxidase degradation pathways have been suggested for O. anthropi strain GPK3 (Sviridov et al. 2012). Despite the fact that the genetic potential for successful glyphosate/AMPA degradation seems rather generalized among environmental bacteria, the differences found among bacterial strains could be attributed to a range of factors including differences in i) cellular $\mathrm{P}$ requirements and $\mathrm{P}$ storage or ii) enzyme affinities and/or catalytic efficiencies for glyphosate and/or AMPA.

Metabolite concentration analyses shed some light on degradation pathways used by bacteria to degrade glyphosate and/or AMPA. On the one hand, the AMPA degradation pathway was similar among all the strains. After complete AMPA dissipation, the five strains accumulated very low concentrations of metabolites, mostly formaldehyde. Also, formaldehyde did not accumulate in the media probably because of incorporation in the microbial biomass via the tetrahydrofolate cycle (Wang et al. 2016b). On the other hand, strains CNI28, CNI35 and CNI52 accumulated formaldehyde and glycine after glyphosate transformation. Since no intermediary AMPA or sarcosine metabolites were detected, we can suggest that both C-P lyase and/or glyphosate oxidase degradation pathways could take place. Very low concentrations of easily degradable metabolites are detected at the end of exponential decay phases for glyphosate in CNI28, CNI35 and CNI52 suggesting the incorporation of these metabolites in the microbial biomass or release in the form of $\mathrm{CO}_{2}$.

The glyphosate degradation pathway was different in the strain Acidovorax sp. CNI26, compared to CNI28, CNI35 and CNI52, since it accumulated sarcosine. Sarcosine results from the direct cleavage of the C-P bond by C-P lyases yielding sarcosine and Pi (Figure 1). The detection of this metabolite proves, at least, the existence of the C-P lyase degradation pathway by CNI26 but does not exclude that both the C-P lyase and oxidative pathways were occurring in parallel. This is especially true when comparing the different accumulations of sarcosine and formaldehyde by CNI26 at the end of experiments I and II (see section 3.3 and 3.4). Unfortunately, not all glyphosate/AMPA metabolites were measured in this experiment (glyoxylate and methylamine were missing) to be able to better refine glyphosate/AMPA degradation pathways employed by the different bacterial strains.

The specific analysis of C-P lyase and glycine oxidase genes in Acidovorax sp. CNI26 revealed different expression patterns depending on $\mathrm{P}$ treatments. The increased expression of C-P lyase and glycine oxidase genes at 124 hours in the glyphosate treatment showed that i) 
651

652

653

654

655

656

657

658

659

660

661

662

663

664

665

666

667

668

669

670

C-P lyase certainly contributed to sarcosine accumulation in the media and ii) glycine oxidase could contribute to parallel oxidation of sarcosine. Indeed, glycine oxidase from Bacillus subtilis (Martínez-Martínez et al. 2006) and/or other microbial species (Sviridov et al. 2015) has been proven to be capable of oxidative deamination of various amines, including sarcosine. Consequently, the differences in sarcosine accumulation between the first and second experiments suggest that oxidation of sarcosine by glycine oxidase may become relevant in later stages of glyphosate decomposition (Job et al. 2002). In the AMPA treatment, expression levels of both C-P lyase and glycine oxidase were high at 36 hours indicating AMPA degradation by C-P lyase as well as methylamine degradation by glycine oxidase. The expression level of these two enzymes decreased at $48 \mathrm{~h}$ when neither AMPA nor metabolites remained in the media.

\section{CONCLUSION}

The present study show that stream biofilms can host bacterial species capable to grow and metabolize both glyphosate and AMPA and other species only capable to metabolize AMPA. The close interactions between microbial species in biofilms are expected to guarantee the survival of species such as Ensifer $s p$. CNII15 tolerant to glyphosate but only able to metabolize AMPA. It must be noted that this study constrained each bacterial strain to use $\mathrm{P}$ from glyphosate or AMPA, although other P sources may be available for bacteria in stream biofilms. Hence, glyphosate mitigation by microbial biofilms still depends on $\mathrm{P}$ concentration levels in stream waters.

\section{ACKNOWLEDGMENTS}

This work was supported by the French National Research Agency in the frame of the BIGLY project (ANR-16-CE32-0001).

\section{REFERENCES}

Artigas, J., Batisson, I., Carles, L., 2020. Dissolved organic matter does not promote glyphosate degradation in auto-heterotrophic aquatic microbial communities. Environ. Poll. 259, 113951. 
Araya, R., Yamaguchi, N., Tani, K., Nasu, M., 2003. Change in the bacterial community of natural river biofilm during biodegradation of aniline-derived compounds determined by denaturing gradient gel electrophoresis. J. Health Sci. 49, 379-385.

Batisson, I., Crouzet, O., Besse-Hoggan, P., Sancelme, M., Mangot, J.F., Mallet, C., Bohatier, J., 2009. Isolation and characterization of mesotrione-degrading Bacillus sp. from soil. Environ. Pollut. 157, 1195-1201.

Battaglin, W.A., Meyer, M.T., Kuivila, K.M., Dietze, J.E., 2014. Glyphosate and its degradation product AMPA occur frequently and widely in US soils, surface water, groundwater, and precipitation. J. Am. Water Resour. Assoc. 50, 275-290.

Bazot, S., Lebeau, T., 2008. Simultaneous mineralization of glyphosate and diuron by a consortium of three bacteria as free-and/or immobilized-cells formulations. Appl. Microbiol. Biotechnol. 77, 1351-1358.

Benbrook, C. M., 2016. Trends in glyphosate herbicide use in the United States and globally. Environ. Sci. Eur. 28, 1-15.

Bhatt, P., Joshi, T., Bhatt, K., Zhang, W., Huang, Y., Chen, S., 2021. Binding interaction of glyphosate with glyphosate oxidoreductase and C-P lyase: Molecular docking and molecular dynamics simulation studies. J. Hazardous Materials 409, 124927.

Bonnet, J.L., Bonnemoy, F., Dusser, M., Bohatier, J., 2007. Assessment of the potential toxicity of herbicides and their degradation products to nontarget cells using two microorganisms, the bacteria Vibrio fischeri and the ciliate Tetrahymena pyriformis. Environ. Toxicol. 22, 78-91.

Borggaard, O.K., Gimsing, A.L., 2008. Fate of glyphosate in soil and the possibility of leaching to ground and surface waters: a review. Pest Manag. Sci. 64, 441-456.

Borrel, G., Lehours, A.C., Crouzet, O., Jézéquel, D., Rockne, K., Kulczak, A., Duffaud, E., Joblin, K., Fonty, G., 2012. Stratification of Archaea in the Deep Sediments of a Freshwater Meromictic Lake: Vertical Shift from Methanogenic to Uncultured Archaeal Lineages. PLoS ONE 7, 1-14.

Carles, L., Gardon, H., Joseph, L., Sanchís, J., Farré, M., Artigas, J., 2019. Meta-analysis of glyphosate contamination in surface waters and dissipation by biofilms. Environ. Int. 124, 284-293.

Chen, C.M., Ye, Q.Z., Zhu, Z.M., Wanner, B.L., Walsh, C.T., 1990. Molecular biology of carbon-phosphorus bond cleavage. Cloning and sequencing of the phn (psiD) genes involved in alkylphosphonate uptake and C-P lyase activity in Escherichia coli B. J. Biol. Chem. 265, 4461-4471. 
Daouk, S., Copin, P.J., Rossi, L., Chevre, N., Pfeifer, H.R., 2013. Dynamics and environmental risk assessment of the herbicide glyphosate and its metabolite AMPA in a small vineyard river of the Lake Geneva catchment. Environ. Toxicol. Chem. 32, 2035-2044.

Directive 2009/128/EC of the European Parliament and of the Council of 21 October 2009 establishing a framework for Community action to achieve the sustainable use of pesticides.

Duke, S.O., Powles, S.B., 2008. Glyphosate: a once-in-a-century herbicide Pest Manag. Sci., 64, 319-325.

Ecophyto II+ (2018) Ministère de la Transition écologique et solidaire. https://agriculture.gouv.fr/le-plan-ecophyto-quest-ce-que-cest. Website visited the 28th August 2020.

Grandcoin, A., Piel, S., Baures, E., 2017. AminoMethylPhosphonic acid (AMPA) in natural waters: Its sources, behavior and environmental fate. Water Res. 117, 187-197.

Horth, H., Blackmore, K., 2009. Survey of glyphosate and AMPA in groundwaters and surface waters in Europe. WRC Rep. No UC8073 2.

Hove-Jensen, B., Zechel, D.L., Jochimsen, B., 2014. Utilization of glyphosate as phosphate source: biochemistry and genetics of bacterial carbon-phosphorus lyase. Microbiol Mol Biol Rev 78, 176-197.

Jacob, G., Garbow, J., Hallas, L., Kimack, N., Kishore, G., Schaefer, J., 1988. Metabolism of Glyphosate in Pseudomonas Sp Strain Lbr. Appl. Environ. Microbiol. 54, 2953-2958.

Job, V., Marcone, G. L., Pilone, M. S., Pollegioni, L., 2002. Glycine oxidase from Bacillus subtilis. Characterization of a new protein. J. Biol. Chem. 277, 6985-6993.

Lamichhane, J.R., Dachbrodt-Saaydeh, S., Kudsk, P., Messéan, A., 2016. Towar a reduced reliance on convetional pesticide in european agriculture. American Phytopatol. Soc. $100,10-24$.

Lawrence, J.R., Kopf, G., Headley, J.V., Neu, T.R., 2001. Sorption and metabolism of selected herbicides in river biofilm communities. Can. J. Microbiol. 47, 634-641.

Maggi, F., la Cecilia, D., Tang, F.H.M., McBrateny, A., 2020. The global environmental hazard of glyphosate use. Sci. Total Environ. 717, 137-167.

Mallat, E., Barceló, D., 1998. Analysis and degradation study of glyphosate and of aminomethylphosphonic acid in natural waters by means of polymeric and ionexchange solid-phase extraction columns followed by ion chromatography-postcolumn derivatization with fluorescence detection. J. Chromatogr. A 823, 129-136. 
Malmqvist, B., Rundle S., 2002. Threats to the running water ecosystems of the world. Environmental Conservation 29, 134-153.

Martínez- Martínez, I., Navarro- Fernández, J., Lozada- Ramírez, J.D., García- Carmona, F. and Sánchez- Ferrer, Á., 2006. Maximization of Production of His- Tagged Glycine Oxidase and Its M261 Mutant Proteins. Biotechnol. Progress, 22, 647-652.

Mcauliffe, K., Hallas, L., Kulpa, C., 1990. Glyphosate Degradation by AgrobacteriumRadiobacter Isolated from Activated-Sludge. J. Ind. Microbiol. 6, 219-221.

Metcalf, W. W., Wanner, B. L., 1993. Evidence for a fourteen-gene, phnC to phnP locus for phosphonate metabolism in Escherichia coli. Gene 129, 27-32.

Meybec, M., 2003. Global analysis of river systems: from Earth system controls to Anthropocene syndromes. Phil. Trans. R. Soc. Lond. B 358, 1935-1955.

Meybeck, M., Helmer, R., 1989. The quality of rivers: from pristine stage to global pollution. Palaeogeography, Palaeoclimatology, Palaeoecology (Global and Planetary Change Section) 75, 283-309.

Murphy, J., Riley, J., 1962. A modified single solution method for the determination of phosphate in natural waters. Anal. Chim. Acta 27, 31-36.

Nowack, B., 2003. Environmental chemistry of phosphonates. Water Res. 37, 2533-2546.

Okada, E., Costa, J.L., Bedmar, F., 2016. Adsorption and mobility of glyphosate in different soils under no-till and conventional tillage. Geoderma 263, 78-85.

Pedotti, M., Rosini, E., Molla, G., Moschetti, T., Savino, C., Vallone, B., et al., 2009. Glyphosate resistance by engineering the flavoenzyme glycine oxidase. J. Biol. Chem. 284, 36415-36423.

Pfaffl, M.W., 2001. A new mathematical model for relative quantification in real-time RTPCR. Nucleic Acids Res. 29, 45e-445.

Pipke, R., Schulz, A., Amrhein, N., 1987. Uptake of glyphosate by an Arthrobacter sp. Appl. Environ. Microbiol. 53, 974-978.

Rampazzo, N., Rampazzo Todorovic, G., Mentler, A., Blum, W.E.H., 2013. Adsorption of glyphosate and aminomethylphosphonic acid in soils. Int. Agrophysics 27, 203-209.

Rossi, F., Mallet, C., Portelli, C., Donnadieu, F., Bonnemoy, F., Artigas, J., 2019. Stimulation or inhibition: Leaf microbial decomposition in streams subjected to complex chemical contamination, Sci. Total Environ, 648, 1371-1383.

Schwarzenbach, R.P., Egli, T., Hofstetter, T.B., von Gunten, U., Wehrli, B., 2010. Global water pollution and human health. Annu. Rev. Environ. Resourc. 35,109-136. 
Sidoli, P., Baran, N., Angulo-Jaramillo, R., 2016. Glyphosate and AMPA adsorption in soils: laboratory experiments and pedotransfer rules. Environ. Sci. Pollut. Res. 23, 57335742 .

Stosiek, N., Talma, M., Klimek-Ochab, M., 2019. Carbon-Phosphorus Lyase-the State of the Art. Appl. Biochem. Biotechnol. 1-28.

Struger, J., Van Stempvoort, D.R., Brown, S.J., 2015. Sources of aminomethylphosphonic acid (AMPA) in urban and rural catchments in Ontario, Canada: Glyphosate or phosphonates in wastewater? Environ. Pollut. 204, 289-297.

Studnik, H., Liebsch, S., Forlani, G., Wieczorek, D., Kafarski, P., Lipok, J., 2015. Amino polyphosphonates-chemical features and practical uses, environmental durability and biodegradation. New Biotechnol. 32, 1-6.

Sviridov, A.V., Shushkova, T.V., Ermakova, I.T., Ivanova, E.V., Epiktetov, D.O., Leontievsky, A.A., 2015. Microbial degradation of glyphosate herbicides (Review). Appl. Biochem. Microbiol. 51, 188-195

Sviridov, A.V., Shushkova, T.V., Ermakova, I.T., Ivanova, E.V., Leontievsky, A.A., 2014. Glyphosate: safety risks, biodegradation, and bioremediation, in: Current Environmental Issues and Challenges. Springer, pp. 183-195.

Sviridov, A.V., Shushkova, T.V., Zelenkova, N.F., Vinokurova, N.G., Morgunov, I.G., Ermakova, I.T., Leontievsky, A.A., 2012. Distribution of glyphosate and methylphosphonate catabolism systems in soil bacteria Ochrobactrum anthropi and Achromobacter sp. Appl. Microbiol. Biotechnol. 93, 787-796.

Talbot, H.W., Johnson, L.M., Munnecke, D.M., 1984. Glyphosate utilization byPseudomonas sp. andAlcaligenes sp. isolated from environmental sources. Curr. Microbiol. 10, 255259.

Tien, C.J., Lin, M.C., Chiu, W.H., Chen, C.S., 2013. Biodegradation of carbamate pesticides by natural river biofilms in different seasons and their effects on biofilm community structure. Environ. Pollut. 179, 95-104.

Toledo-Arana, A., Dussurget, O., Nikitas, G., Sesto, N., Guet-Revillet, H., Balestrino, D., Loh, E., Gripenland, J., Tiensuu, T., Vaitkevicius, K., Barthelemy, M., Vergassola, M., Nahori, M.-A., Soubigou, G., Régnault, B., Coppée, J.-Y., Lecuit, M., Johansson, J., Cossart, P., 2009. The Listeria transcriptional landscape from saprophytism to virulence. Nature 459, 950-956. 
Untergasser, A., Nijveen, H., Rao, X., Bisseling, T., Geurts, R., Leunissen, J. A. M., 2007. Primer3Plus, an enhanced web interface to Primer3. Nucleic Acids Research 35, 71 74.

Vereecken, H., 2005. Mobility and leaching of glyphosate: a review. Pest Manag. Sci. Former. Pestic. Sci. 61, 1139-1151.

Vörösmarty, C.J., McIntyre, P.B., Gessner, M.O., Dudgeon, D., Prusevich, A., Green, P., Glidden, S., Bunn, S.E., Sullivan, C.A., Reidy Liermann C., Davies, P.M., 2010. Global threats to human water security and river biodiversity. Nature 467, 555-561.

Wang, S., Liu, B., Yuan, D., Ma, J., 2016a. A simple method for the determination of glyphosate and aminomethylphosphonic acid in seawater matrix with high performance liquid chromatography and fluorescence detection. Talanta 161, 700706.

Wang, S., Seiwert, B., Kästner, M., Miltner, A., Schäffer, A., Reemtsma, T., Yang, Q., Nowak, K.M., 2016b. (Bio)degradation of glyphosate in water-sediment microcosms A stable isotope co-labeling approach. Water Res. 99, 91-100.

Yang, X., Wang, F., Bento, C.P.M., Meng, L., van Dam, R., Mol, H., Liu, G., Ritsema, C.J., Geissen, V., 2015. Decay characteristics and erosion-related transport of glyphosate in Chinese loess soil under field conditions. Sci. Total Environ. 530-531, 87-95.

Zhan, H., Fendg, Y., Fan, X., Chen, S., 2018. Recent advances in glyphosate degradation. Appl. Microbiol. Biotechnol. 102, 5033-5043.

Zhang, Q., van der Donk, W.A., 2012. Answers to the carbon-phosphorus lyase conundrum. ChemBioChem 13, 627-629. 
829 Figure S1. Bacterial density evolution in $\mathrm{K}_{2} \mathrm{HPO}_{4}$ (A), AMPA (B) and glyphosate (C) 830 treatments are shown. Lines correspond to fittings to the Gompertz growth model 831 (SGompertz) with mean parameters values for each condition. The values are means \pm 832 standard errors $(n=3)$ of the experimental data.

833

A

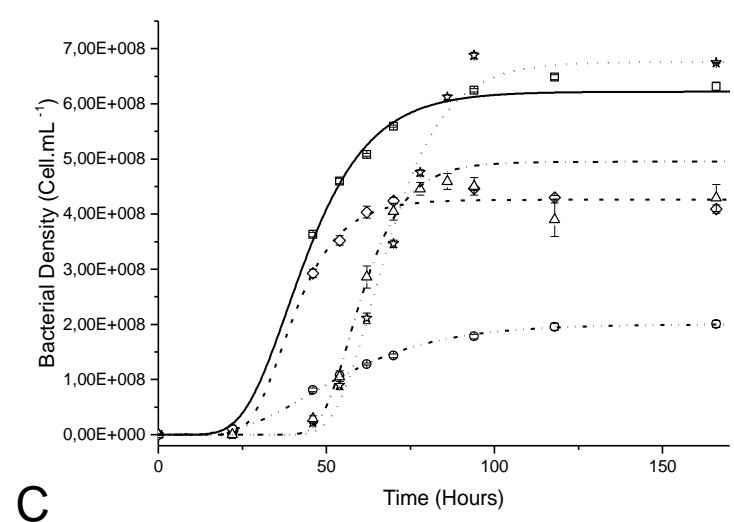

C

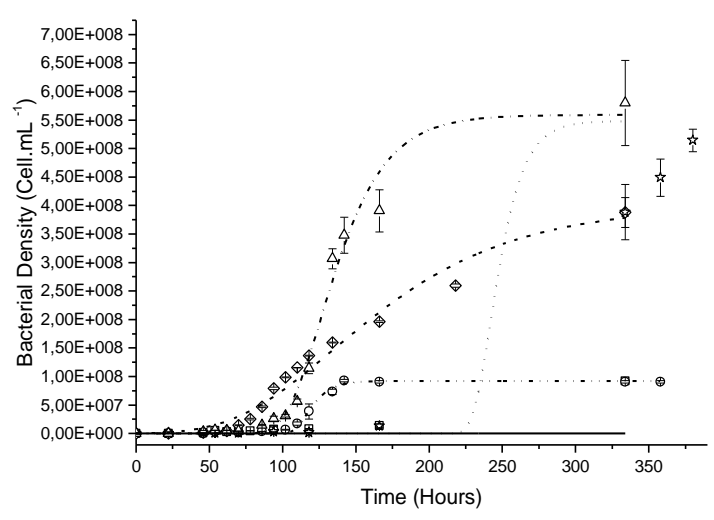

B

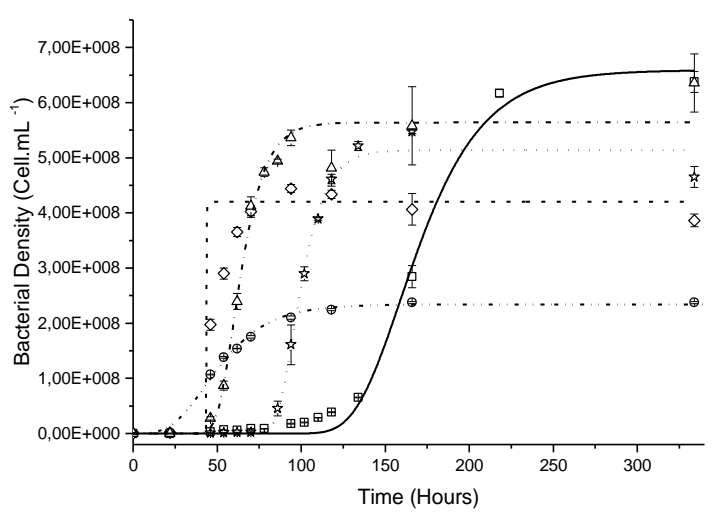

834 
Table S1. Bacterial isolates known for their glyphosate-degrading activity. In addition to the 16S rDNA gene sequences of the 5 newly isolated strains (present study), sequences from previously isolated glyphosate-degrading strains were included in the phylogenetic analysis (Figure 2). These sequences were taken from the studies listed by the review of Sviridov et al. (2015), as well as from more recent studies.

\begin{tabular}{|c|c|c|c|c|c|c|c|c|}
\hline Strain & Source & Metabolite & Metabolism & Reference & $\begin{array}{l}\text { NCBI Accession } \\
\text { Number }\end{array}$ & Alternative strain & $\begin{array}{l}\mathrm{NCBI} \\
\text { Accession } \\
\text { Number }\end{array}$ & Reference \\
\hline $\begin{array}{l}\text { Arthrobacteratrocyaneus } \\
\text { ATCC } 13752\end{array}$ & Cell-collection & AMPA & $\mathrm{P}$ & (Pipke and Amrhein, 1988) & X80746.1 & & & \\
\hline Arthrobactersp. GLP-1 & Unknown & Sarcosine & NP & (Pipke et al., 1987) & NA & Arthrobactersp. R-II-1 & AB017541.1 & Unpublished \\
\hline Streptomyceslusitanus & Cell-collection & Unknown & NP & (Lipok et al., 2009) & NA & $\begin{array}{l}\text { Streptomyceslusitanus strain OUCT } \\
16-27\end{array}$ & MH532549.1 & Unpublished \\
\hline Streptomycessp. StC & Activ-sludge & Sarcosine & NP & (Obojska et al., 1999) & NA & Streptomycessp. strain YP127 & MF102228.1 & Unpublished \\
\hline Flavobacteriumsp. GD1 & Activ-sludge & AMPA & $\mathrm{P}$ & (Balthazor and Hallas, 1986) & NA & Flavobacteriumsp. CC-JY-6 & DQ239767.1 & Unpublished \\
\hline Spirulinaspp. & Cell-collection & Unknown & NP & (Lipok et al., 2007) & NA & Spirulina laxissima SAG 256.80 & DQ393278.1 & Unpublished \\
\hline Bacillus cereus CB4 & GP-Soil & AMPA & C & (Fan et al., 2012) & JN887351.1 & & & \\
\hline Bacillus subtilis Bs-15 & Rhizosphere & Unknown & $\mathrm{CP}$ & (Yu et al., 2015) & KX783560.1 & & & \\
\hline $\begin{array}{l}\text { Geobacilluscaldoxylosilyticus } \\
\text { T20 }\end{array}$ & Industrial & AMPA & $\mathrm{P}$ & (Obojska et al., 2002) & NA & $\begin{array}{l}\text { Geobacilluscaldoxylosilyticus strain } \\
\text { S1812 }\end{array}$ & NR_028708.1 & $\begin{array}{l}\text { (Ahmad et } \\
\text { al., 2000) }\end{array}$ \\
\hline Ochrobactrumanthropi GDOS & GP-Soil & AMPA & $P$ & (Hadi et al., 2013) & JF831448.1 & & & \\
\hline Ochrobactrumanthropi GPK 3 & GP-Soil & AMPA & $P$ & (Sviridov et al., 2012) & NA & & & \\
\hline Ochrobactrumanthropi LBAA & Soil & AMPA & $\mathrm{P}$ & $\begin{array}{l}\text { (Gard et al., 1997; Obojska } \\
\text { et al., 2002) }\end{array}$ & NA & & & \\
\hline Ochrobactrumanthropi S5 & Soil & AMPA & $P$ & (Gard et al., 1997) & NA & & & \\
\hline $\begin{array}{l}\text { Ochrobactrumpituitosum } \\
\text { CNI52 }\end{array}$ & River-biofilm & Unknown & $P$ & This study & MN017830 & & & \\
\hline Agrobacteriumradiobacter & Activ-sludge & Sarcosine & $P$ & (Wackett et al., 1987) & NA & Agrobacteriumtumefaciens P5 & KX255008.1 & Unpublished \\
\hline $\begin{array}{l}\text { Agrobacteriumradiobacter } \\
\text { SW9 }\end{array}$ & Activ-sludge & AMPA & C & (Mcauliffe et al., 1990) & NA & & & \\
\hline $\begin{array}{l}\text { Agrobacteriumtumefaciens } \\
\text { CNI28 }\end{array}$ & River-biofilm & Unknown & $\mathrm{P}$ & This study & MN017828 & & & \\
\hline
\end{tabular}




\begin{tabular}{|c|c|c|c|c|c|c|c|c|}
\hline Rhizobium meliloti 1021 & Unknown & Sarcosine & $\mathrm{P}$ & (Liu et al., 1991) & NA & Sinorhizobiummeliloti strain LU12 & EU182657.2 & Unpublished \\
\hline Sinorhizobiumsp. CNII15 & River-biofilm & Unknown & $P$ & This study & MN017826 & & & \\
\hline Novosphingobiumsp. CNI35 & River-biofilm & Unknown & $P$ & This study & MN017829 & & & \\
\hline Achromobacter sp. Kg 16 & GP-Soil & Unknown & $\mathrm{P}$ & $\begin{array}{l}\text { (Ermakova et al., 2010; } \\
\text { Shushkova et al., 2016) }\end{array}$ & NA & Achromobacter sp. CH1 & HQ619222.1 & Unpublished \\
\hline Achromobacter sp. LW9 & Activ-sludge & AMPA & C & (Mcauliffe et al., 1990) & NA & & & \\
\hline Achromobacter sp. MPK 7 & GP-Soil & Sarcosine & $P$ & (Ermakova et al., 2017) & NA & & & \\
\hline Achromobacter sp. MPS 12A & $\begin{array}{l}\text { phosphonate- } \\
\text { Soil }\end{array}$ & Sarcosine & $\mathrm{P}$ & (Sviridov et al., 2012) & NA & & & \\
\hline Alcaligenessp. GL & Cyanobacteria & Sarcosine & $\mathrm{P}$ & (Lerbs et al., 1990) & NA & Alcaligenessp. PGBS001 & EU622578.1 & Unpublished \\
\hline Burkholderiasp. AQ5-13 & GP-Soil & Unknown & $P$ & (Manogaran et al., 2017) & KX792234.1 & & & \\
\hline $\begin{array}{l}\text { Burkholderiavietnamiensis } \\
\text { AQ5-12 }\end{array}$ & GP-Soil & Unknown & $\mathrm{P}$ & (Manogaran et al., 2017) & KX792233.1 & & & \\
\hline Acidovoraxsp. CNI26 & River-biofilm & Unknown & $P$ & This study & MN017827 & & & \\
\hline Enterobactercloacae K7 & Rhizosphere & Sarcosine & $P$ & (Kryuchkova et al., 2014) & NA & Enterobactercloacae strain ST23 & KU049660.1 & Unpublished \\
\hline Klebsiellaoxytoca SAW-5 & GP-Soil & Unknown & C & (Sabullah et al., 2016) & NA & Klebsiellaoxytoca strain ATCC 13182 & NR_119277.1 & $\begin{array}{l}\text { (Boye and } \\
\text { Hansen, } \\
\text { 2003) }\end{array}$ \\
\hline Providenciaalcalifaciens & GP-Soil & AMPA & C & (Nourouzi et al., 2011) & NA & $\begin{array}{l}\text { Providenciaalcalifaciens strain } \mathrm{Cl} \\
\text { P82.90 }\end{array}$ & NR_042053.1 & $\begin{array}{l}\text { (Dauga, } \\
\text { 2002) }\end{array}$ \\
\hline Pseudomonas fluorescens & Soil & AMPA & $P$ & (Zboińska et al., 1992) & NA & $\begin{array}{l}\text { Pseudomonas fluorescens strain SG- } \\
1\end{array}$ & KU291443.1 & $\begin{array}{l}\text { (Carles et } \\
\text { al., 2017) }\end{array}$ \\
\hline $\begin{array}{l}\text { Pseudomonas pseudomallei } \\
22\end{array}$ & GP-Soil & AMPA & $\mathrm{P}$ & $\begin{array}{l}\text { (Peñaloza-Vazquez et al., } \\
\text { 1995) }\end{array}$ & NA & $\begin{array}{l}\text { Burkholderiapseudomallei strain } \\
\text { ATCC } 23343\end{array}$ & NR_043553.1 & $\begin{array}{l}\text { (Glass et al., } \\
\text { 2006) }\end{array}$ \\
\hline Pseudomonas putida T5 & HC-Soil & Sarcosine & $P$ & $\begin{array}{l}\text { (Selvi and Manonmani, } \\
\text { 2015) }\end{array}$ & NA & $\begin{array}{l}\text { Pseudomonas putida strain IAM } \\
1236\end{array}$ & NR_043424.1 & $\begin{array}{l}\text { (Anzay et } \\
\text { al., 1997) }\end{array}$ \\
\hline Pseudomonas sp. 4ASW & GP-Soil & Sarcosine & $P$ & (Dick and Quinn, 1995) & NA & & & \\
\hline Pseudomonas sp. GA07 & GP-Soil & AMPA & C & (Zhao et al., 2015) & KР671491 & & & \\
\hline Pseudomonas sp. GA09 & GP-Soil & AMPA & C & (Zhao et al., 2015) & KP671492 & & & \\
\hline Pseudomonas sp. GCO4 & GP-Soil & AMPA & C & (Zhao et al., 2015) & KP671493 & & & \\
\hline Pseudomonas sp. GLC11 & Unknown & Sarcosine & $\mathrm{P}$ & $\begin{array}{l}\text { (Selvapandiyan and } \\
\text { Bhatnagar, 1994) }\end{array}$ & NA & & & \\
\hline
\end{tabular}




\begin{tabular}{|l|l|l|l|l|l|l|}
\hline Pseudomonas sp. LBr & Activ-sludge & AMPA & P & (Jacob et al., 1988) & NA \\
\hline Pseudomonas sp. PG2982 & Unknown & Sarcosine & P & (Moore et al., 1983) & NA \\
\hline Pseudomonas sp. SG-1 & Activ-sludge & AMPA & P & (Talbot et al., 1984) & NA & \\
\hline Stenotrophomonasmaltophilia & GP-Soil & AMPA & C & (Nourouzi et al., 2011) & NA & $\begin{array}{l}\text { Stenotrophomonasmaltophilia strain } \\
\text { IAM 12423 }\end{array}$ \\
\hline
\end{tabular}

